\title{
Modelling potential production of macroalgae farms in UK and Dutch coastal waters
}

\author{
Johan van der Molen ${ }^{1,2}$, Piet Ruardij ${ }^{2}$, Karen Mooney $^{4}$, Philip Kerrison ${ }^{5}$, Nessa E. O'Connor ${ }^{4}$, Emma Gorman $^{4}$, \\ Klaas Timmermans ${ }^{3}$, Serena Wright ${ }^{1}$, Maeve Kelly ${ }^{5}$, Adam D. Hughes ${ }^{5}$, and Elisa Capuzzo ${ }^{1, a}$ \\ ${ }^{1}$ The Centre for Environment, Fisheries and Aquaculture Science (Cefas), Lowestoft, NR33 0HT, UK \\ ${ }^{2}$ NIOZ Royal Netherlands Institute for Sea Research, Dept. of Coastal Systems and Utrecht University, \\ Den Burg, 1797 SZ, the Netherlands \\ ${ }^{3}$ NIOZ Royal Netherlands Institute for Sea Research, Dept. of Estuarine and Delta Systems and Utrecht University, \\ Yerseke, $4401 \mathrm{NT}$, the Netherlands \\ ${ }^{4}$ Queen's University, Belfast, BT7 1NN, UK \\ ${ }^{5}$ The Scottish Association for Marine Science (SAMS), Oban, PA37 1QA, UK \\ ${ }^{a}$ now at: The Centre for Environment, Fisheries and Aquaculture Science (Cefas), Weymouth, DT4 8UB, UK
}

Correspondence: Johan van der Molen (johan.van.der.molen@nioz.nl)

Received: 17 May 2017 - Discussion started: 14 June 2017

Revised: 15 December 2017 - Accepted: 11 January 2018 - Published: 23 February 2018

\begin{abstract}
There is increasing interest in macroalgae farming in European waters for a range of applications, including food, chemical extraction for biofuel production. This study uses a 3-D numerical model of hydrodynamics and biogeochemistry to investigate potential production and environmental effects of macroalgae farming in UK and Dutch coastal waters. The model included four experimental farms in different coastal settings in Strangford Lough (Northern Ireland), in Sound of Kerrera and Lynn of Lorne (north-west Scotland) and in the Rhine plume (the Netherlands), as well as a hypothetical large-scale farm off the UK north Norfolk coast. The model could not detect significant changes in biogeochemistry and plankton dynamics at any of the farm sites averaged over the farming season. The results showed a range of macroalgae growth behaviours in response to simulated environmental conditions. These were then compared with in situ observations where available, showing good correspondence for some farms and less good correspondence for others. At the most basic level, macroalgae production depended on prevailing nutrient concentrations and light conditions, with higher levels of both resulting in higher macroalgae production. It is shown that under non-elevated and interannually varying winter nutrient conditions, farming success was modulated by the timings of the onset of increasing nutrient concentrations in autumn and nutrient drawdown
\end{abstract}

in spring. Macroalgae carbohydrate content also depended on nutrient concentrations, with higher nutrient concentrations leading to lower carbohydrate content at harvest. This will reduce the energy density of the crop and thus affect its suitability for conversion into biofuel. For the hypothetical large-scale macroalgae farm off the UK north Norfolk coast, the model suggested high, stable farm yields of macroalgae from year to year with substantial carbohydrate content and limited environmental effects.

\section{Introduction}

\subsection{Background, aims and approach}

Worldwide macroalgae (seaweed) production is in excess of 28 million tons per year and has doubled between 2000 and 2014 (FAO, 2014). The majority of this production ( > 95\%) is from the southeast Asian region where macroalgal cultivation is well established (FAO, 2014; West et al., 2016). The harvested macroalgae biomass is mainly used directly for human consumption, although other uses include the extraction of phycocolloids (gelling agents), animal feed, fertiliser, water remediation and probiotics in aquaculture (see Van der Burg et al., 2016; West et al., 2016). 
There has been increasing interest in the potential of macroalgae cultivation across the Northern Hemisphere and Europe (Van der Burg et al., 2016), partially driven by research on biofuel technologies (Kerrison et al., 2015). The characteristics of Phaeophyta macroalgae, in particular high productivity, fast growth rate and high polysaccharide content, make them a suitable biomass for biofuel production (Hughes et al., 2012; Kerrison et al., 2015; Schiener et al., 2017; Fernand et al., 2017). A further advantage is that such third-generation biofuels do not need additional freshwater and do not compete for agricultural land like many existing biofuel sources.

Marine macroalgae fix $\mathrm{CO}_{2}$, acting as a sink for anthropogenic $\mathrm{CO}_{2}$ ("blue carbon"; Nellemann et al., 2009; Duarte et al., 2017), and absorb dissolved nutrients from the water column, helping to remediate nutrient release from anthropogenic sources such as agricultural runoff, waste water treatment and aquaculture ("bioremediation"; e.g. Chopin et al., 2001; Lüning and Pang, 2003; Fei, 2004; He et al., 2008; Sanderson et al., 2012; Smale et al., 2013). Therefore, largescale cultivation and harvesting of macroalgae could play a role in removing carbon from the marine environment, as well as in reduction of coastal nutrient enrichment.

Kelp species, such as Saccharina latissima (a brown algae), have been identified as candidate macroalgae for bioenergy production (Kerrison et al., 2015). Its cultivation has been trialled across Europe, including Scotland, Strangford Lough in Northern Ireland, the southern North Sea and northwest of Spain (Buck and Buchholz, 2004; Sanderson et al., 2012; Peteiro et al., 2006; Kerrison et al., 2015; Van der Burg et al., 2016).

Kelp naturally occurs in sublittoral coastal waters in temperate and polar regions. These macroalgae aggregations have been shown to modify the surrounding environment by reducing water velocity and attenuating waves (Jackson, 1997; Gaylord et al., 2007), and by modifying sedimentation rates of suspended particles (Eckman et al., 1989). They are also associated with high biodiversity (Burrows, 2012), providing numerous ecosystem services including habitat, shelter and food for many species including fish (Hartney, 1996), benthic organisms (lobster, crabs; Bologna and Steneck, 1993; Daly and Konar, 2008), herbivorous organisms (Kang et al., 2008) and birds (Fredriksen, 2003); see also Walls et al. (2017).

While a large-scale kelp farm might replicate some of the ecosystem services of a natural kelp forest, assumptions as to the extent of the similarity should be considered with caution (Wood et al., 2017). Since kelp farms are monocultures suspended within the water column and are likely to undergo a yearly cycle of growth and harvesting, they are not synonymous with mature kelp beds which contain multiple species of different ages attached to the benthos (Wood et al., 2017).

Studies on the potential environmental effects of macroalgae farms are limited. This lack of information, in combination with limited knowledge on expected farm yields, re-

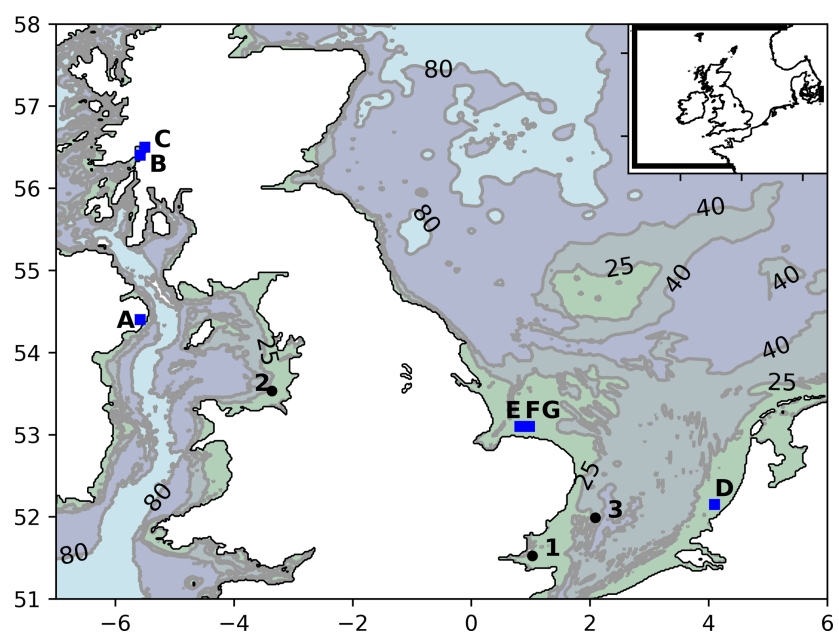

Figure 1. Study area with SmartBuoy stations (black circles: 1 is Warp Anchorage, 2 is Liverpool Bay, 3 is west Gabbard; www. cefas.co.uk/cefas-data-hub/smartbuoys) and macroalgae farm locations (blue squares represent the macroalgae farms: A is Strangford Lough; B is Sound of Kerrera; C is Lynn of Lorne; D is Rhine plume; E-G are north Norfolk; see Table 4 for more information). Depths are in metres. Inset: North-west European Shelf seas with model domain boundaries (thick black lines).

sults in uncertainty for potential investors, developers and macroalgae farmers, as well as legislators, who provide the relevant farming licence (Wood et al., 2017).

The aim of this modelling study was to investigate environmental effects and potential yield of macroalgae farms, at different locations in UK and Dutch coastal waters, using the European Regional Seas Ecosystem Model - Biogeochemical Flux Model (ERSEM-BFM). In particular, five farms were simulated: four experimental farms (Sound of Kerrera and Lynn of Lorne, Scotland; Strangford Lough, Northern Ireland; the Rhine region of freshwater influence - ROFI, the Netherlands) and a hypothetical farm (Norfolk, UK) (Fig. 1). Observations from the experimental farms in Scotland and Northern Ireland were used to ground truth the model.

\subsection{Saccharina latissima}

Saccharina latissima, or sugar kelp, is a subtidal phaeophyte macroalga native to Europe, common to UK rocky shores. It is a brown algae, with leather/rubbery texture, which in the adult form is constituted by a holdfast, a stipe and a large undivided blade (or frond, or lamina), with undulated margins (Kain, 1979; White and Marshal, 2007).

The growth of $S$. latissima is affected by environmental factors such as light availability, wave action and water currents, nutrient concentration, type of substratum, temperature, salinity and grazing pressure (Lobban and Harrison, 1997; Birkett et al., 1998). A recent study by Kerrison et al. (2015) summarises the optimal range of environmental 
Table 1. Variables of the macroalgae model.

\begin{tabular}{lll}
\hline Symbol & Unit & Description \\
\hline$W_{\mathrm{s}}$ & $\mathrm{mg} \mathrm{C} \mathrm{m}^{-2}$ & Structural biomass, state variable \\
$A$ & $\mathrm{~m}^{2}$ & Frond area \\
$W_{\mathrm{C}}$ & $\mathrm{mg} \mathrm{C} \mathrm{m}^{-2}$ & Total biomass, state variable \\
$W_{\mathrm{N}}$ & $\mathrm{mmol} \mathrm{N} \mathrm{m}^{-2}$ & Biomass, state variable \\
$W_{\mathrm{P}}$ & $\mathrm{mmol} \mathrm{m}^{-2}$ & Biomass, state variable \\
$W_{\mathrm{L}}$ & $\mathrm{mg} \mathrm{Chl} \mathrm{m}^{-2}$ & Biomass, state variable \\
$\mu$ & $\mathrm{d}^{-1}$ & Specific growth rate (area), derived variable \\
$W_{\mathrm{W}}$ & $\mathrm{g}$ & Total wet weight of sporophyte, derived variable \\
$W_{\mathrm{d}}$ & $\mathrm{g}$ & Total dry weight, derived variable \\
$E(d)$ & $\mu \mathrm{mol} \mathrm{photons} \mathrm{m}^{-2} \mathrm{~s}^{-1}$ & Irradiance (PAR), environmental variable at depth $d$ \\
$T(d)$ & ${ }^{\circ} \mathrm{C}$ & Water temperature, environmental variable at depth $d$ \\
$N$ & $\mathrm{mmol} \mathrm{m}$ & Substrate nutrient concentration, environmental variable \\
\hline
\end{tabular}

variables for $S$. latissima growth (see Table 1 in Kerrison et al., 2015).

In coastal waters around the UK, kelp species show high growth rates from late autumn to early summer. This is then followed by a slower growth phase between July and December (Parke, 1948; Kain, 1963). Maximum length developments are also associated with maximum fresh weights (Parke, 1948; Black, 1950).

Kelp plants show effective uptake of nutrients (ammonium, nitrate and phosphate) from seawater (Birkett et al., 1998; Kregting et al., 2014; Kregting et al., 2016). When nutrients are abundant and exceed metabolic requirements, these plants have the ability to store nutrients in the plant tissues (Birkett et al., 1998). For example, S. latissima has been shown to store nitrogen reserves at levels of more than 1000 times the external ambient concentration (Chapman et al., 1978).

S. latissima stores energy in the form of carbohydrates (e.g. mannitol and laminarin), the concentrations of which vary widely during the year and peak in the second part of the year (Black, 1950; Kain, 1979; Bartsch et al., 2008; Schiener et al., 2017). For example, Gévaert et al. (2001) observed that for S. latissima in the English Channel, the maximum carbon content is reached in September with the lowest concentrations occurring in March. Similar trends have also been reported for Norway (Sjøtun, 1993) and Scotland (Connolly and Drew, 1985). The minimum carbon concentration in March occurs when the growth rate of the algae is high and the plant growth is carried out at the expense of carbohydrate reserves. In contrast, during summer, carbon assimilation exceeds carbon utilisation, allowing the formation of carbon reserves (Gévaert et al., 2001).

The presence of these carbohydrate reserves and a fast growth rate make $S$. latissima an interesting potential species for production of renewable energy (Kraan, 2013; Fernand et al., 2017). For these reasons, S. latissima has become a focus for experimental farming in Europe. For a comprehensive summary of modelling efforts on S. latissima, we refer the reader to Broch and Slagstad (2012) and references therein.

\section{Methods}

\subsection{GETM-ERSEM-BFM model}

\subsubsection{GETM: North-west European Shelf setup}

The 3-D hydrodynamic General Estuarine Transport Model (GETM; www.getm.eu; Burchard and Bolding, 2002) solves the shallow water, heat balance and density equations. It uses the General Ocean Turbulence Model (GOTM; Burchard et al., 1999; www.gotm.net) to solve the vertical dimension. GETM was run using the North-west European Shelf setup that has been used by Van der Molen et al. (2016) to study the potential large-scale effects of tidal energy generation in the Pentland Firth, and by Van der Molen et al. (2017) to develop a suspended particulate matter model. The setup includes a spherical grid covering the area 46.4 $63^{\circ} \mathrm{N}, 17.25^{\circ} \mathrm{W}-13^{\circ} \mathrm{E}$, with a resolution of $0.08^{\circ}$ longitude and $0.05^{\circ}$ latitude (approximately $5.5 \mathrm{~km}$ ), and 25 nonequidistant layers in the vertical. The model bathymetry was based on the North West Shelf Operational Oceanographic System (NOOS) bathymetry (www.noos.cc/index.php?id= 173). The model was forced with tidal constituents derived from TOPEX-POSEIDON satellite altimetry (Le Provost et al., 1998); atmospheric forcing from ECMWF ERAInterim (Dee et al., 2011; Berrisford et al., 2011; www. ecmwf.int/en/research/climate-reanalysis/era-interim); interpolated river runoff from a range of observational data sets (the National River Flow Archive (www.ceh.ac.uk/data/ nrfa/index.html) for UK rivers; the Agence de l'eau LoireBretagne, Agence de l'eau Seine-Normandie and IFREMER for French rivers, the DONAR database for Netherlands rivers; ARGE Elbe, the Niedersächsisches Landesamt für Ökologie and the Bundesanstalt für Gewässerkunde for 
German rivers; the Institute for Marine Research, Bergen, for Norwegian rivers (see also Lenhart et al., 2010); and depth-resolved temperature and salinity boundary conditions from ECMWF-ORAS4 (Mogensen et al., 2012; Balmaseda et al., 2013; https://www.ecmwf.int/en/research/climatereanalysis/ocean-reanalysis). Boundary conditions for nutrients are taken from the World Ocean Atlas monthly climatology (Garcia et al., 2010).

\subsubsection{Macroalgae farm representation in ERSEM}

The ERSEM-BFM version used here (1 June 2016) is a development of the model ERSEM III (see Baretta et al., 1995; Ruardij and Van Raaphorst, 1995; Ruardij et al., 1997, 2005; Vichi et al., 2003, 2004, 2007; Van der Molen et al., 2013, 2014, 2016; www.nioz.nl/en/about/cos/ coastal-systems-modelling) and describes the dynamics of the biogeochemical fluxes within the pelagic and benthic environment. The ERSEM-BFM model simulates the cycles of carbon, nitrogen, phosphorus, silicate and oxygen and allows for variable internal nutrient ratios and chlorophyll content inside organisms, based on external availability and physiological status. The model applies a functional group approach and contains five pelagic phytoplankton groups, four main zooplankton groups and five benthic faunal groups, the latter comprising four macrofauna and one meiofauna groups. Pelagic and benthic aerobic and anaerobic bacteria are also included. The pelagic module includes transparent exopolymer particle (TEP) excretion by diatoms under nutrient stress, the associated formation of macro-aggregates consisting of TEPs and diatoms, leading to enhanced sinking rates and food supply to the benthic system especially in the deeper offshore areas (Engel, 2000), a Phaeocystis functional group for improved simulation of primary production in coastal areas (Peperzak et al., 1998), a pelagic filterfeeder larvae stage and benthic diatoms, including resuspension, transport and pelagic growth. The suspended particulate matter (SPM) module, included for improved simulation of the underwater light climate, contains contributions by waves and currents, and full 3-D transport (Van der Molen et al., 2017). Finally, the model includes resuspension of particulate organic matter as a proportion of the SPM resuspension and also 3-D transport.

A macroalgae functional type representing Saccharina latissima was introduced in ERSEM-BFM, closely following the implementation of Broch and Slagstad (2012) (see Fig. 2 for a schematic diagram of the implementation). The macroalgae were represented by a non-advective biomass concentration, in analogy to other ERSEM functional types. To conform with the structure of ERSEM, phosphate dynamics were added in analogy to the nitrate dynamics, as well as assuming an optimum $\mathrm{N} / \mathrm{P}$ ratio for structural mass of 25, slightly below the median reported by Atkinson and Smith (1983); see also Duarte (1992). The nutrient uptake method for the macroalgae was changed to the dynamic

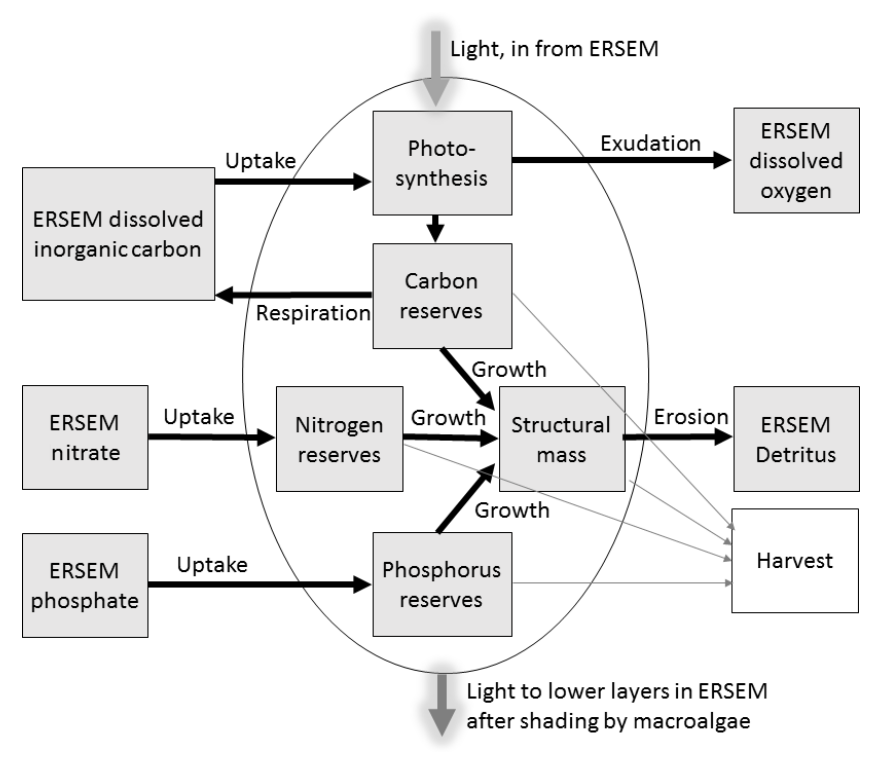

Figure 2. Schematic representation of the farmed macroalgae in ERSEM-BFM, modified and expanded after Broch and Slagstad (2012).

one presented by Droop $(1973,1974)$ in order to be consistent with the nutrient uptake of phytoplankton in ERSEM (Baretta-Bekker et al., 1997). Ammonium uptake was also added. The method includes growth, mortality (simulated by an equation that relates apical frond loss exponentially to frond area), nutrient and carbon biogeochemistry, and effects of light, temperature and nutrient concentrations. Plant structural biomass, nutrient buffers and carbohydrate biomass were represented separately. For inclusion in ERSEM-BFM, the macroalgae were represented in terms of biomass density rather than frond dimensions. The revised set of variables, parameters and equations is given in Tables 1 to 3 . The effect of macroalgae on light extinction was included both within the layer containing macroalgae and on the layers below. Only farmed macroalgae were included in the model. The implementation of farms assumed the use of lines as an anchoring material. Farms were prescribed, per model grid cell, in terms of line length, number of lines, depth below the surface, deployment and harvest time, and initial biomass and plant density (see Table 4 for detail). For the calculations, the model converts these data to biomass density in the model layer coinciding with the depth of the lines below the surface. The simulated farms coinciding with the experimental farms in Strangford Lough, Sound of Kerrera, Lynn of Lorne and the Rhine plume were given dimensions coinciding with typical deployments. The background of the dimensions of the north Norfolk farm (Fig. 1, Sites E-G) is given in Sect. 2.2.4. To facilitate the comparisons, all simulations used the same deployment and harvest dates. 
Table 2. Parameters of the macroalgae model.

\begin{tabular}{|c|c|c|c|}
\hline Symbol & Value & Unit & Description \\
\hline$q_{\mathrm{S}}^{A}$ & $83 \times 10^{-6}$ & $\mathrm{~m}^{2}(\mathrm{mgC})^{-1}$ & Unit area per structural mass \\
\hline$\gamma$ & 0.5 & $\mathrm{~g} \mathrm{C}\left(\mathrm{g} \mathrm{C}^{-1}\right.$ & Exudation parameter \\
\hline$\varepsilon$ & 22 & $\mathrm{~m}^{-2}$ & Frond erosion parameter \\
\hline$A_{0}$ & 0.06 & $\mathrm{~m}^{2}$ & Growth rate parameter \\
\hline$m_{1}$ & 0.1085 & - & Growth rate parameter \\
\hline$m_{2}$ & 0.03 & - & Growth rate parameter \\
\hline$\mu_{\mathrm{m}}^{\overline{\mathrm{S}}}$ & 0.36 & $\mathrm{~d}^{-1}$ & Maximal specific growth of structural biomass (uncorrected for day length) \\
\hline$\mu_{\mathrm{m}}^{\mathrm{C}}$ & 0.36 & $d^{-1}$ & Maximal specific growth of biomass (uncorrected for day length) \\
\hline$q_{\mathrm{CS}}^{1}$ & 0.05 & $\mathrm{gC}\left(\mathrm{gC}^{-1}\right.$ & Minimal quotum reserve $\mathrm{C}$ per structural mass \\
\hline$q_{\mathrm{NS}}^{\mathrm{I}}$ & $0.142 \times 10^{-3}$ & $\operatorname{mol~N}\left(\mathrm{g} \mathrm{C}^{-1}\right.$ & Minimal quotum $\mathrm{N}$ per structural mass \\
\hline$q_{\mathrm{PS}}^{1}$ & $6 \times 10^{-6}$ & $\operatorname{molP}\left(\mathrm{g} \mathrm{C}^{-1}\right.$ & Minimal quotum $\mathrm{P}$ per structural mass \\
\hline$q_{\mathrm{NC}}^{\mathrm{m}}$ & $0.3 \times 10^{-3}$ & $\operatorname{mol~N}\left(\mathrm{g} \mathrm{C}^{-1}\right.$ & Maximal quotum $\mathrm{N}$ per total mass carbon \\
\hline$q_{\mathrm{PC}}^{\mathrm{m}}$ & $12 \times 10^{-6}$ & $\operatorname{molP}\left(\mathrm{g} \mathrm{C}^{-1}\right.$ & Maximal quotum $\mathrm{P}$ per total mass carbon \\
\hline$q_{\mathrm{C}}^{\mathrm{L}}$ & 0.0278 & $\operatorname{g~Chl~}\left(\mathrm{g} \mathrm{C}^{-1}\right.$ & Optimal quotum chlorophyll per total mass carbon \\
\hline$K_{e}$ & 20 & $\mu \mathrm{mol}$ photons $\mathrm{m}^{-2} \mathrm{~s}^{-1}$ & $\begin{array}{l}\text { Light affinity parameter (lowest light intensity at which primary production is } \\
\text { optimal) }\end{array}$ \\
\hline$a_{\mathrm{N}}$ & $0.5 \times 10^{-3}$ & $\mathrm{~m}^{3}(\mathrm{mg} \mathrm{C})^{-1} \mathrm{~d}^{-1}$ & Nutrient affinity for nitrogen \\
\hline$a_{\mathrm{P}}$ & $0.7 \times 10^{-3}$ & $\mathrm{~m}^{3}(\mathrm{mgC})^{-1} \mathrm{~d}^{-1}$ & Nutrient affinity for phosphate \\
\hline$q_{10}$ & 2 & - & $Q_{10}$ parameter \\
\hline$n_{\mathrm{pl}}$ & user-defined & $m^{-2}$ & Initial number of macrophyte plants per unit area \\
\hline$r^{\mathrm{C}}$ & 0.01 & $\mathrm{~d}^{-1}$ & Specific respiration of the total biomass $\left(W_{\mathrm{C}}\right)$ \\
\hline
\end{tabular}

\subsection{Macroalgae farms}

\subsubsection{Strangford Lough research farm}

The Northern Irish farm site run by Queen's University, Belfast, is located at $54.4^{\circ} \mathrm{N}, 5.58^{\circ} \mathrm{W}$, within the semienclosed Strangford Lough (Fig. 1, Site A). The lough covers an area of approximately $134 \mathrm{~km}^{2}$, with water depths from 0 to $70 \mathrm{~m}$, is $8 \mathrm{~km}$ long, and the Narrows $(0.5 \mathrm{~km}$ wide at narrowest) connect the Irish Sea to the main inlet of the lough (Smyth et al., 2016; Kregting and Elsäßer, 2014). The lough is fully saline, ranging from 32 to 34 with negligible freshwater input from three small point sources (Boyd, 1973; Smith, 2010) and is predominantly well mixed (Taylor and Service, 1997). The experimental site is located off the southern shore in the vicinity of the Narrows but is relatively sheltered with an average current speed of $0.3 \mathrm{~m} \mathrm{~s}^{-1}$. The current predominantly runs in a west-east direction (Mooney-McAuley et al., 2016). There can be moderate wave action when the wind is coming from northerly and easterly directions. The depth profile is variable, ranging from 2 to $13 \mathrm{~m}$ at the mean low water spring.

The Strangford Lough research farm is located near the south-western shore of the lough (Fig. 1, Site A). The farm cultivated a mixture of $S$. latissima, Laminaria digitata and Alaria esculenta. Here, we use observations from the 20122013 deployment, when $2 \times 100 \mathrm{~m}$ long lines of S. latissima were cultivated and 19 with the other species. The growing lines were suspended horizontally at $1 \mathrm{~m}$ below the surface and were pre-seeded at deployment. Monthly sampling was carried out after 2 months at sea. At each sampling time, five samples were taken from each rope removing all plants on a $30 \mathrm{~cm}$ section. The total wet biomass of all plants in these $30 \mathrm{~cm}$ intervals was determined and used to calculate the mean biomass per line ( $\mathrm{kg}$ wet weight $\left.\mathrm{m}^{-1}\right)$. Total number of plants, and total wet and dry biomass were measured. Total length, blade length, blade width and stipe length were also measured for the 12 largest plants in the sample. For the purpose of this modelling study, we have assumed that all 21 lines of the farm were cultivated with S. latissima; only field observations from the $S$. latissima long lines were used.

The mean biomass per line ( $\mathrm{kg}$ wet weight $\mathrm{m}^{-1}$ ) was used to estimate the total farm carbon biomass for comparison with the model results (see Sect. 3.3.1). Overall, 354 samples were analysed for wet and dry weight, giving a combined total wet weight of $3549.9 \mathrm{~kg}$ and a dry weight of $380.38 \mathrm{~kg}$, resulting in a wet/dry weight ratio of 9.333 . For conversion from dry weight to carbon weight, we assume that the dry plant material consists predominantly of $\mathrm{CH}_{2} \mathrm{O}$ groups (Atkinson and Smith, 1983), resulting in a dry weight to carbon ratio of $32 / 12=2.67$. The resulting conversion factor from wet weight to carbon is 24.919 . 
Table 3. Equations of the macroalgae model. The last column lists the numbers of the corresponding equations used by Broch and Slagstad (2012).

\begin{tabular}{|c|c|c|c|}
\hline Equation & Unit & Description & \\
\hline$\mu=\mu_{\mathrm{m}}^{\mathrm{S}} f_{A} f_{\mathrm{L}}^{\mathrm{S}} f_{T}^{\mathrm{S}}\left(1-\max \left\{\frac{W_{\mathrm{S}} q_{\mathrm{NS}}^{1}}{W_{\mathrm{N}}}, \frac{W_{\mathrm{S}} q_{\mathrm{PS}}^{1}}{W_{\mathrm{P}}, W_{\mathrm{S}} q_{\mathrm{CS}}^{1}}\right\}\right)$ & $d^{-1}$ & Specific growth rate & 2 \\
\hline$A=q_{\mathrm{S}}^{A} W_{\mathrm{S}} / n_{\mathrm{pl}}$ & $\mathrm{m}^{2}$ & Calculation of frond surface & \\
\hline$f_{A}(A)=\left(m_{1}\left(e^{-\left(A / A_{0}\right)^{2}}\right)+m_{2}\right) /\left(m_{1}+m_{2}\right)$ & - & $\begin{array}{l}\text { Non-dimensional effect of size area on } \\
\text { growth rate }\left(0<f_{A}<1\right)\end{array}$ & 3 \\
\hline$f_{T}^{\mathrm{C}}(d)=q_{10}^{(T(d)-10) / 10}$ & - & $\begin{array}{l}\text { Effect of temperature on C-fixation rate; as- } \\
\text { sumed is an exponential increase }\end{array}$ & 14 \\
\hline$f_{T}^{\mathrm{S}}(d)=f_{T}^{\mathrm{C}}(d)\left\{\frac{19-T(d)}{21-T(d)}\right\}$ & - & $\begin{array}{l}\text { Effect of temperature on structural growth; } \\
\text { structural growth is inhibited above } 19^{\circ} \mathrm{C}\end{array}$ & 4 \\
\hline$f_{\mathrm{L}}^{\mathrm{C}}(d)=1-\exp \left(-\frac{W_{\mathrm{L}}}{W_{\mathrm{C}} q_{\mathrm{C}}^{\mathrm{L}}} \frac{E(d)}{K_{e}}\right)$ & - & $\begin{array}{l}\text { Light limitation for } \mathrm{C} \text { fixation at depth } d \text { is } \\
\text { dependent on Chl : } \mathrm{C} \text { quotum and on light } \\
\text { energy } E \text { at depth } d\end{array}$ & 5 \\
\hline$f_{\mathrm{L}}^{\mathrm{S}}(d)=\left(f_{\mathrm{L}}^{\mathrm{C}}(d)>0\right)$ & - & Only structural growth at daylight & 5 \\
\hline$v(A)=\frac{10^{-6} e^{\varepsilon A}}{1+10^{-6}\left(e^{\varepsilon A}-1\right)}$ & $d^{-1}$ & Frond erosion & 6 \\
\hline$u_{n}^{\mathrm{m}}=a_{n} n W_{\mathrm{C}}$ & $\mathrm{mmol} n \mathrm{~d}^{-1}$ & $\begin{array}{l}\text { Maximal nutrient uptake for } n \text { is nitrogen } \\
(\mathrm{N}) \text { and for } n \text { is phosphate }(\mathrm{P})\end{array}$ & 8 \\
\hline$e_{\mathrm{C}}=1-\exp \left[-\gamma \frac{W_{\mathrm{C}}-\left(1-q_{\mathrm{CS}}^{1}\right) W_{\mathrm{S}}}{W_{\mathrm{S}}}\right]$ & $d^{-1}$ & $\begin{array}{l}\text { Carbon exudation only when more } \mathrm{C} \text { re- } \\
\text { serves are present than the minimum quo- } \\
\text { tum } q_{\mathrm{CS}}^{1}\end{array}$ & 15 \\
\hline$\rho_{\mathrm{L}}=q_{\mathrm{C}}^{\mathrm{L}} f_{\mathrm{L}}^{\mathrm{C}}\left(\frac{W_{\mathrm{C}}}{W_{\mathrm{L}}} q_{\mathrm{C}}^{\mathrm{L}}\right) \frac{K_{e}}{E(d)}$ & $\mathrm{gChl}\left(\mathrm{g} \mathrm{C}^{-1}\right.$ & $\begin{array}{l}\text { The } \rho_{\mathrm{L}} \text { determines the size of the chloro- } \\
\text { phyll (L) production; low light and a low } \\
\text { quotum } \mathrm{Chl}: \mathrm{C} \text { enhance this production }\end{array}$ & \\
\hline$\frac{\mathrm{d} W_{n}}{\mathrm{~d} t}=\min \left\{u_{n}^{\mathrm{m}},\left(q_{\mathrm{nC}}^{\mathrm{m}} \mu+\mu_{\mathrm{m}}^{\mathrm{C}}\left(q_{\mathrm{nC}}^{\mathrm{m}}-\frac{W_{n}}{W_{\mathrm{C}}}\right)\right) W_{\mathrm{C}}+f_{T}^{\mathrm{C}} r^{\mathrm{C}} W_{n}\right\}$ & $\mathrm{mmol} n \mathrm{~m}^{-2} \mathrm{~d}^{-1}$ & $\begin{array}{l}\text { Rate of change in total content of } n \text { is nitro- } \\
\text { gen }(\mathrm{N}) \text { and of } n \text { is phosphate }(\mathrm{P})\end{array}$ & 7,8 \\
\hline$\frac{\mathrm{d} W_{\mathrm{C}}}{\mathrm{d} t}=\left(\mu_{\mathrm{m}}^{\mathrm{C}} f_{\mathrm{L}}^{\mathrm{C}}-e_{\mathrm{C}}-f_{T}^{\mathrm{C}} r^{\mathrm{C}}\right) W_{\mathrm{C}}$ & $\mathrm{mgC} \mathrm{m}{ }^{-2} \mathrm{~d}^{-1}$ & Rate of change in total carbon content & 9,10 \\
\hline$\frac{\mathrm{d} W_{\mathrm{L}}}{\mathrm{d} t}=\rho_{\mathrm{L}}\left(\mu_{\mathrm{m}}^{\mathrm{C}} f_{\mathrm{L}}^{\mathrm{C}}-e_{\mathrm{C}}-f_{T}^{\mathrm{C}^{\mathrm{C}}} r^{\mathrm{C}}\right) W_{\mathrm{C}}$ & $\mathrm{mg} \mathrm{Chl} \mathrm{m}{ }^{-2} \mathrm{~d}^{-1}$ & $\begin{array}{l}\text { Total chlorophyll production by macro- } \\
\text { phytes }\end{array}$ & \\
\hline$\frac{\mathrm{d} W_{\mathrm{S}}}{\mathrm{d} t}=(\mu-v) W_{\mathrm{S}}$ & $\mathrm{mgCm}^{-2} \mathrm{~d}^{-1}$ & Rate of change of structural biomass & 1 \\
\hline
\end{tabular}

\subsubsection{Sound of Kerrera and Lynn of Lorne research farms}

The Sound of Kerrera and Lynn of Lorne farms (Fig. 1, Sites B and C) are located in the Firth of Lorne and operated by the Scottish Association for Marine Science (SAMS).

The first Scottish farm site was located at $56.38^{\circ} \mathrm{N}$, $5.54^{\circ} \mathrm{W}$ within the Sound of Kerrera (Fig. 1, Site B) which separates the island Kerrera from the mainland by approximately $500 \mathrm{~m}$, near Oban. The Sound reaches $60 \mathrm{~m}$ depth and experiences a semi-diurnal tidal current of $0.77 \mathrm{~m} \mathrm{~s}^{-1}$ during spring tides. The island shelters the Sound from all but the predominant south-westerly winds from the Atlantic. At the farm site, the depth ranges from 5 to $25 \mathrm{~m}$.

The farm at Sound of Kerrera (Fig. 1, Site B) consists of $180 \mathrm{~m}$ of double-headed long line buoyed by mussel floats, with growing lines suspended at $1.5 \mathrm{~m}$ depth. For the Sound of Kerrera farm, observations of nutrient concentrations, light and temperature are available from a 17-month period in 2013-2014. Nutrient concentrations were collected in triplicates at $1.5 \mathrm{~m}$ depth, whereas light and temperature were collected at half-hourly intervals at $1.5 \mathrm{~m}$ depth, using HOBO Pendant data loggers (Onset Computer Corp, MA, USA). Here, we use the means of the triplicates for nutrients and monthly means for light and temperature. The nutrient data showed a typical seasonal cycle with high winter concentrations and low concentrations following the spring bloom, but with surprisingly high summer concentrations in 2013, which are unexplained. Early summer concentrations in 2014 were substantially lower.

The second Scottish farm is located at $56.49^{\circ} \mathrm{N}, 5.47^{\circ} \mathrm{W}$, in the Lynn of Lorne (Fig. 1, Site C), which separates the island of Lismore from the mainland. The site has a depth ranging from 15 to $25 \mathrm{~m}$ and has a mean current speed of $0.1 \mathrm{~m} \mathrm{~s}^{-1}, 5 \mathrm{~m}$ below the surface. The Lynn of Lorne is $3 \mathrm{~km}$ wide at the location of the farm and thus is very exposed to the predominant south-westerly winds from the Atlantic.

The Lynn of Lorne farm (Fig. 1, Site C) consists of a $100 \times 100 \mathrm{~m}$ grid submerged $3 \mathrm{~m}$ below the surface. This can contain up to 24 lines of $100 \mathrm{~m}$ length, spaced $4 \mathrm{~m}$ apart, with growing lines suspended horizontally at a depth of $1.5 \mathrm{~m}$ below the surface. 
Table 4. Farm parameters as used in the model.

\begin{tabular}{|c|c|c|c|c|c|}
\hline & Strangford Lough & Sound of Kerrera & Lynn of Lorne & Rhine plume & North Norfolk coast \\
\hline Latitude & 54.40 & 56.40 & 56.50 & 52.15 & 53.10 \\
\hline Longitude & -5.58 & -5.58 & -5.50 & 4.10 & $0.82-0.98$ \\
\hline Line length $(\mathrm{m})$ & 100 & 100 & 100 & 85 & 3500 \\
\hline Number of lines per farm & 21 & 24 & 24 & 1 & 350 \\
\hline Distance between lines $(\mathrm{m})^{\mathrm{a}}$ & 5 & 4 & 4 & - & 50 \\
\hline Depth below surface $(\mathrm{m})$ & 1.0 & 1.5 & 1.5 & 2.0 & $0.3^{\mathrm{b}}$ \\
\hline Initial biomass per metre of line $\left(\mathrm{mg} \mathrm{C} \mathrm{m}^{-1}\right)$ & 2500 & 2500 & 2500 & 2500 & 2500 \\
\hline Number of plants per metre of line & 100 & 100 & 100 & 100 & 100 \\
\hline Deployment day of year & 274 & 274 & 274 & 274 & 274 \\
\hline Harvest day of year & 183 & 183 & 183 & 183 & 183 \\
\hline Number of grid cells covered by farm & 1 & 1 & 1 & 1 & 3 \\
\hline Location in Fig. 1 & A & $\mathrm{B}$ & $\mathrm{C}$ & $\mathrm{D}$ & $\mathrm{E}, \mathrm{F}, \mathrm{G}$ \\
\hline
\end{tabular}

${ }^{\mathrm{a}}$ The model worked with an implicit line distance of $1 \mathrm{~m} .^{\mathrm{b}}$ The depth of the farm for north Norfolk was set to $0.3 \mathrm{~m}$ instead of $1.0 \mathrm{~m}$ to compensate for the over-estimated SPM concentrations and corresponding lower light levels.

\subsubsection{Rhine plume experimental farm}

The southern coast of the Netherlands is characterised by shallow water depths $(<25 \mathrm{~m})$, high winter nutrient concentrations (Laane, 2005; Troost et al., 2014) and high turbidity (Pietrzak et al., 2011; Van der Hout et al., 2015). The Dutch coastal area is influenced by the Rhine River and has lowered salinity, potential for episodic salinity stratification (De Ruyter et al., 1997) and a higher N / P ratio due to larger reductions in anthropogenic riverine phosphate loading since the late 1980s (Lenhart et al., 2010).

Another experimental farm, run by the North Sea farm foundation (Stichting Noordzeeboerderij), was deployed for the first time in the autumn of 2016 within the nutrient-rich Rhine ROFI off the port of Scheveningen, the Netherlands (Fig. 1, Site D). The farm consists of a single line of $100 \mathrm{~m}$, undulating between 0 and $4 \mathrm{~m}$ below the surface. Data from this farm will only become available in the summer of 2017. The farm was included in the model to obtain predictions of potential performance.

\subsubsection{Norfolk hypothetical commercial farm}

The north Norfolk coast of the UK is also characterised by shallow water depths, high winter nutrient concentrations (Hydes et al., 1999; Proctor et al., 2003; Foden et al., 2011) and high turbidity (Dyer and Moffatt, 1998; Bristow et al., 2013). Turbidity is higher than off the coast of the Netherlands, resulting in comparatively lower primary production by phytoplankton.

The hypothetical commercial farm off north Norfolk (Fig. 1, Sites E-G) was selected based on the method of Capuzzo et al. (2014), with minor modifications. The method consisted of overlaying maps of suitability scores (optimal, sub-optimal, unsuitable) of key limiting environmental variables (temperature, light, tidal velocity, wave height and nutrient concentrations; Table 5) and spatial-use data (shipping, structures, Marine Protected Areas, wind farms, etc.) in a
GIS system. The modifications applied here consist of slight variations to the threshold levels of certain environmental variables and the adoption of a farming area based on the suitability data rather than rectangles of predefined size.

The area selected by this method was nearly rectangular $\left(53.0545^{\circ} \mathrm{N} 0.7745^{\circ} \mathrm{E}\right.$ to $\left.53.11^{\circ} \mathrm{N} 0.9775^{\circ} \mathrm{E}\right)$ and located off the north Norfolk coast near Wells-next-the-Sea, in approximately $20 \mathrm{~m}$ water depth, between a coastal Marine Protected Area, wind farms and a Marine Conservation Zone further offshore (Fig. 3). On the model grid, this area was approximated by a hypothetical farm covering three adjacent cells of $0.08^{\circ}$ longitude and $0.05^{\circ}$ latitude (approx. $5 \times 5 \mathrm{~km}$; Fig. 1, Sites E-G).

It was assumed that within each grid cell of $25 \mathrm{~km}^{2}$, roughly half of the surface area would be effectively farmed, and the rest would be required for a mesh of navigation corridors for service vessels and occasional navigation lanes for other traffic. As details of such layouts are beyond the resolution of the model, it was assumed for simplicity that a solid block of $3.5 \times 3.5 \mathrm{~km}$ was farmed within each $5 \times 5 \mathrm{~km}$ grid cell with lines $50 \mathrm{~m}$ apart to avoid entanglement.

\subsubsection{Model scenarios}

GETM-ERSEM-BFM was run without macroalgae farms from 1990 to 2011, using initial conditions from an earlier model version. The first 10 years of this simulation were considered as spinup time to enable the biogeochemistry of the model to adjust. The years 2001-2011 constituted the reference conditions (absence of farms). Farming scenarios were run for five consecutive seasons, starting on 1 October in 2006-2010 and running until the end of July of the following year in accordance with potential farming practice. The scenario runs were hot-started for each year from the corresponding conditions of the reference run on 1 October. To detect potential environmental effects, differences with the reference run were calculated from farm-season-averaged, depth-averaged model scenario output for all routinely stored 


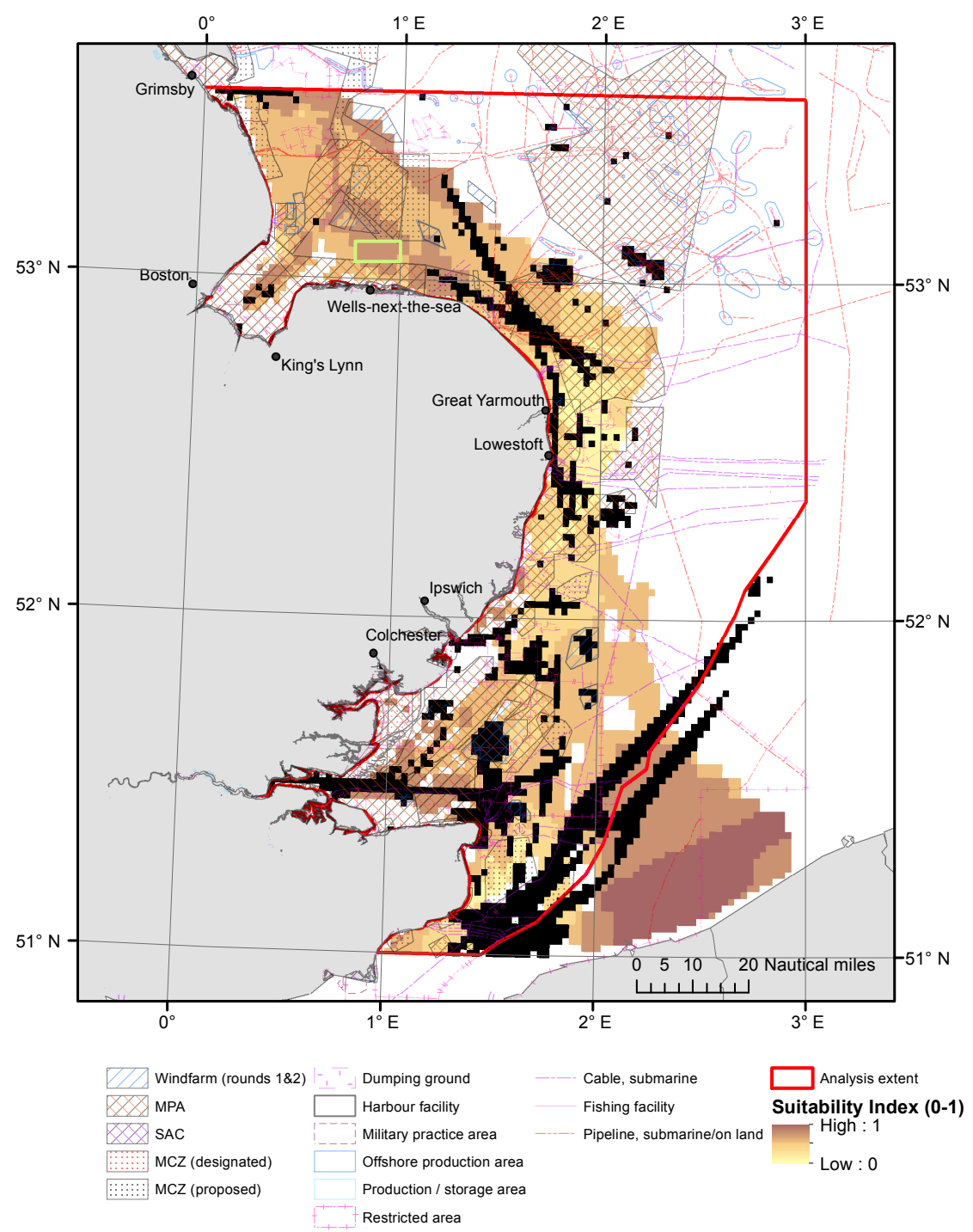

Figure 3. Potential areas for a commercial farm off the north Norfolk coast. Yellow to brown shading: suitability index. Black: moderately high to high shipping intensity (derived from marine vessel automatic identification system ping data obtained from exactEarth Ltd., http: //www.exactearth.com/, for the year 2013). Lines and hashes: various licensed use (obtained on request from the Joint Nature Conservation Committee (JNCC) in 2011 based on the Marine Reference data set, Defra). Green rectangle: selected farm area.

variables (covering nutrient concentrations, functional type biomass and a selection of fluxes for both pelagic and benthic systems), filtered for model variability using the method of Van der Molen et al. (2016) and plotted as maps. The filtering method discarded differences between the reference run and the scenario run that were smaller than similarly calculated differences between the reference run and a duplicate of the reference run. Time series consisting of daily values were extracted for pelagic nutrients, light conditions and macroalgae conditions at each model grid cell containing a macroalgae farm to assess farm performance and functioning.

\subsection{SmartBuoy and satellite observations}

SmartBuoys, which are instrumented moorings (Mills et al., 2005), have been deployed in UK and Dutch waters as components of monitoring programmes and were configured to determine turbidity, chlorophyll fluorescence, salinity, temperature and dissolved oxygen and data processed according to Greenwood et al. (2010). Concentrations of suspended particulate matter and chlorophyll were derived from measurements of turbidity and chlorophyll fluorescence, respectively (Greenwood et al., 2010). Discrete samples were collected using an automated Aquamonitor and subsequently analysed for TOxN (total oxidisable nitrogen) and silicate ac- 
Table 5. Limiting environmental variables for macroalgae cultivation. Ranges in bold were satisfied within the selected farm area (green rectangle in Fig. 3). Between brackets: values suggested by Capuzzo et al. (2014) if different.

\begin{tabular}{lllll}
\hline Variable & Unsuitable & Sub-optimal & Optimal & Reference \\
\hline Contribution to suitability index & 0 & 0.5 & 1 & \\
Minimum temperature $\left({ }^{\circ} \mathrm{C}\right)$ & $<2$ & $\mathbf{2 - 5}(2-4)$ & $>5(>4)$ & Bolton and Lüning (1982) \\
Maximum temperature $\left({ }^{\circ} \mathrm{C}\right)$ & $\begin{array}{l}\text { Adapted farming } \\
\text { methods assumed }\end{array}$ & $\begin{array}{l}\text { Adapted farming } \\
\text { methods assumed }\end{array}$ & $\begin{array}{l}\text { Adapted farming } \\
\text { methods assumed }\end{array}$ & Bolton and Lüning (1982) \\
& possible $(>18)$ & $\begin{array}{l}\text { possible }(16-18) \\
\text { possible }(<16)\end{array}$ & \\
Wave height $(\mathrm{m})$ & $>6$ & $4-6(<1 \& 4-6)$ & $\mathbf{0 - 4}(1-4)$ & Buck and Buchholz (2005) \\
Photic depth $(\mathrm{m})$ & $<1(<2)$ & $1-2(2-4)$ & $>\mathbf{2}(>4)$ & \\
Winter nitrate $\left(\mathrm{mmol} \mathrm{m}^{-3}\right)$ & $<10$ & $10-20$ & $>\mathbf{2 0}$ & Aldridge et al. (2012) \\
Tidal velocity $\left(\mathrm{m} \mathrm{s}^{-1}\right)$ & $>2$ & $<0.25 \& 1.5-2$ & $\mathbf{0 . 2 5}-\mathbf{1 . 5}$ & Buck and Buchholz (2005) \\
Water depth $(\mathrm{m})$ & $<4 \quad(<10 \quad \&$ & & $>\mathbf{4}(10-30)$ & \\
& $>50)$ & & & \\
\hline
\end{tabular}

cording to Gowen et al. (2008). In addition, on most buoys, TOxN was determined using an automated in situ NAS-2E or NAS-3X nutrient analyser. Daily mean values were calculated from all data which passed the quality assurance process.

Daily spatial distributions of chlorophyll concentrations were derived from the MODIS satellite (http: //modis.gsfc.nasa.gov), obtained from the Ifremer ftp server (ftp://ftp.ifremer.fr.:/ifremer/cersat/products/gridded/ ocean-color/atlantic), and were processed as described by Gohin et al. (2005) and Gohin (2011). These data were further processed, in conjunction with modelled surface chlorophyll concentrations, to yield spatially resolved summer and winter statistics of model performance.

\section{Results}

\subsection{Model confirmation}

Modelled $M_{2}$ tidal elevations and currents were compared with observations by Van der Molen et al. (2016), showing reasonable agreement, with elevation amplitudes typically within $20 \mathrm{~cm}$, currents typically within $15 \mathrm{~cm} \mathrm{~s}^{-1}$ and phases for both typically within $30^{\circ}$. Compared with in situ SmartBuoy observations (Greenwood et al., 2010), modelled SPM concentrations showed a reasonable representation of the seasonal cycle but over-estimated peak values. They were mostly within a factor of 3 , and with positive correlations, when compared with satellite observations on a seasonal scale (Van der Molen et al., 2017). These results are not reproduced here.

Surface chlorophyll concentrations from the reference run were compared with satellite observations for 2007-2008 (see also Van der Molen et al., 2016). Winter concentrations (October 2007 to March 2008; Fig. 4a, b) were low in both the model and the satellite data. For a better comparison, the model output was subsampled for each grid cell
(Fig. 4c) using the available clear-sky satellite observations (Fig. 4d). Subsequently, the relative offset (Fig. 4e) and correlation coefficient (Fig. 4f) were calculated. The resulting plots show that the model over-predicted along the northern UK coast and in the coastal areas in the Celtic Sea. Correlations showed a patchy pattern, with typically better correlations along the Dutch and Belgian coasts.

In summer (April 2008 to September 2008; Fig. 5), the model had a small bias in offshore waters but tended to overestimate coastal chlorophyll concentrations. It achieved good correlations in large parts of the North Sea and in parts of the Celtic Sea.

In the vicinity of the north Norfolk farm (Fig. 1, Sites EG), the model bias for surface chlorophyll was slightly negative in winter and the correlation coefficient was low (Fig. 4e, f). In summer, chlorophyll concentrations were slightly overestimated and correlations were moderate (Fig. 5e, f). Near the Rhine plume farm (Fig. 1, Site D), bias was slightly positive and correlations high in winter (Fig. 4e, f), and bias was slightly positive and correlations moderate in summer (Fig. 5e, f).

The model results from the reference run were compared with time series of in situ observations from SmartBuoy for chlorophyll, nitrate, silicate, salinity, temperature and suspended sediment. For Warp Anchorage (see Fig. 1 for location), modelled peak spring-bloom chlorophyll concentrations were within $10 \mathrm{mg} \mathrm{Chl} \mathrm{m}^{-3}$ of the observations for most years (Fig. 6a). The blooms tended to have longer duration than observed. Winter nitrate and silicate concentrations exceeded observed values for most years (Fig. 6b, c) and were related to lower salinity values than observed (Fig. 6d), possibly related to the river forcing or to resolution-related issues with the representation of the river plume. The modelled annual range in temperatures was several degrees more than observed (Fig. 6e), and suspended sediment concentrations were much more variable and had high event-driven peak values (Fig. 6f). 
(a)

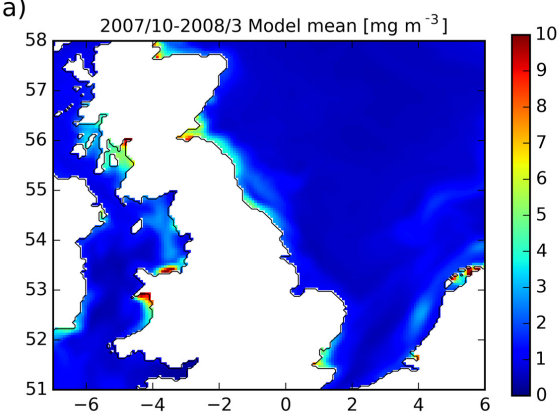

(c)

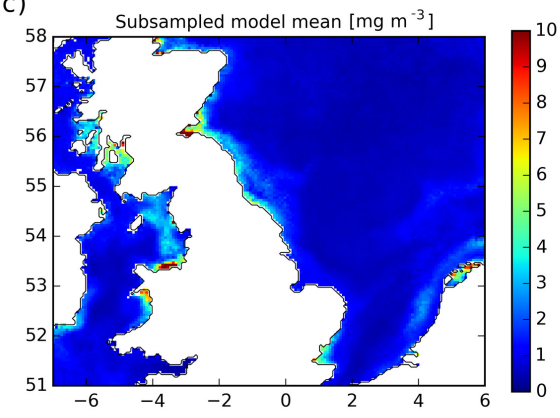

(e)

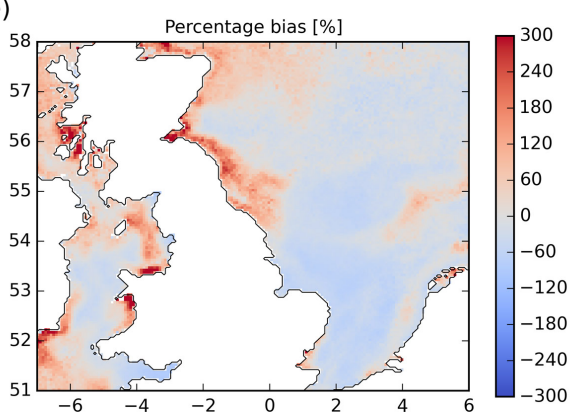

(b)

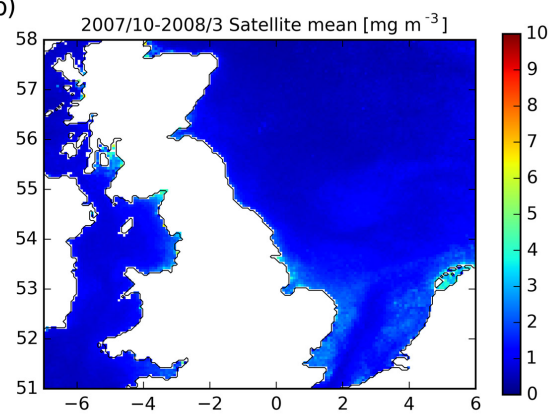

(d)

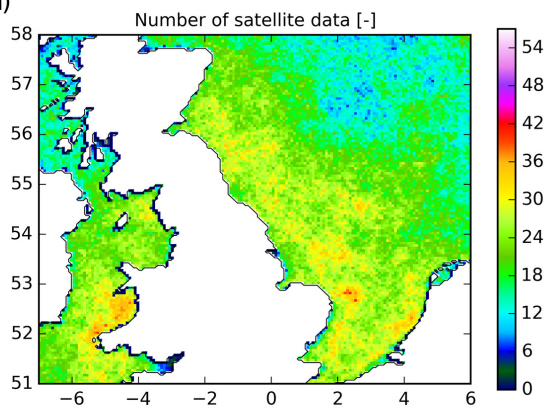

(f)

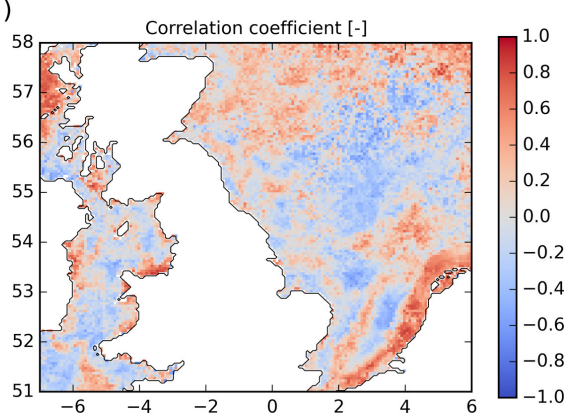

Figure 4. Comparison of winter chlorophyll- $a$ concentrations between model and satellite (October 2007 to March 2008). (a) Model mean; (b) satellite mean; (c) model mean accounting for cloudy days; (d) number of clear days from satellite; (e) relative model bias; (f) correlation coefficient.

In Liverpool Bay (see Fig. 1 for location), spring and summer chlorophyll concentrations generally exceeded observed values from the SmartBuoy by a factor of 2 (Fig. 7a). Nitrate concentrations were reproduced well in the last 5 years of the simulation but were over-estimated in the first four winters (Fig. 7b). Winter silicate concentrations were also higher in the first few years but exceeded observed winter values for all the years in the time series (Fig. 7c). Modelled salinities were slightly higher than observed (Fig. 7d), and there was no apparent relationship with winter nutrient concentrations as for Warp Anchorage. Summer temperatures were reproduced mostly within a degree, while winter temperatures were under-estimated by up to $2{ }^{\circ} \mathrm{C}$ (Fig. 7e). The seasonal cycle of SPM concentrations was reproduced but with substantially higher variability (Fig. 7f).

At the more offshore location of west Gabbard (see Fig. 1), peak chlorophyll concentrations were under-estimated for most, but not all, of the years (Fig. 8a). Nitrate concen- trations were under-estimated by a factor of $2-3$ (Fig. 8b), whereas silicate concentrations were reproduced fairly closely (Fig. 8c). Summer salinities were over-estimated by $0.8-1.2$ (Fig. 8d). Maximum summer temperatures were exceeded by up to $2{ }^{\circ} \mathrm{C}$ in most years, and minimum winter temperatures were, with a few exceptions, reproduced closely (Fig. 8e). Winter suspended sediment concentrations were 4-5 times higher than observed, with much higher variability (Fig. 8f). This general pattern was also observed at other offshore SmartBuoys (not shown here for brevity).

\subsection{Environmental effects}

None of the maps of differences in biogeochemistry and plankton dynamics with the reference run, averaged over the farming season, showed detectable changes in the region of any of the farm sites; i.e. any differences between the run with farms and the first reference run were smaller than or of similar magnitude to differences between the two reference 
(a)

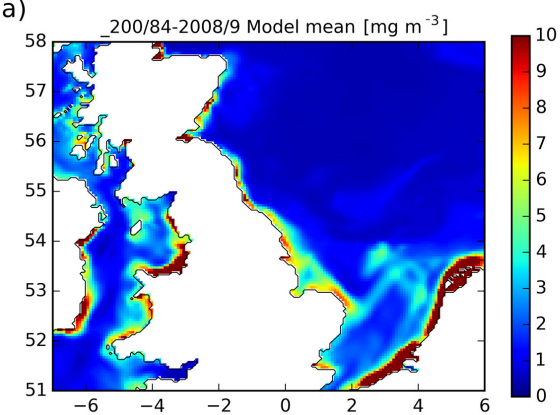

(c)

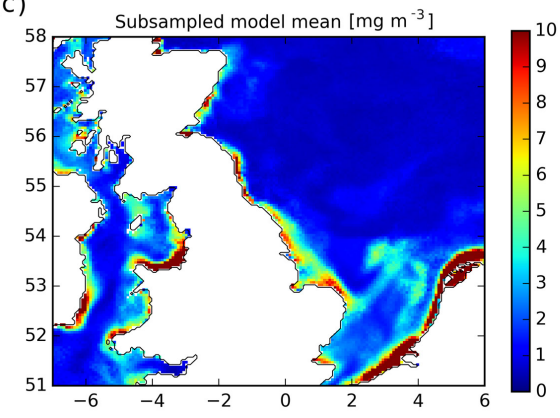

(e)

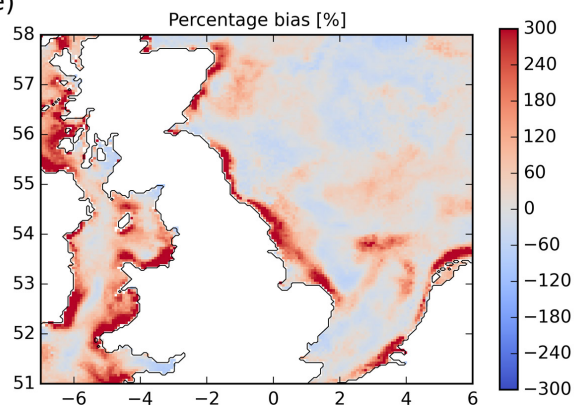

(b)

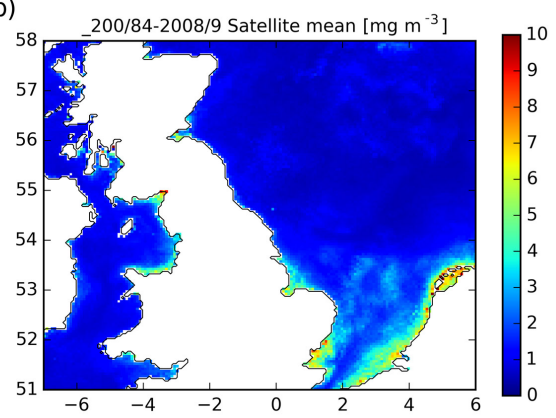

(d)

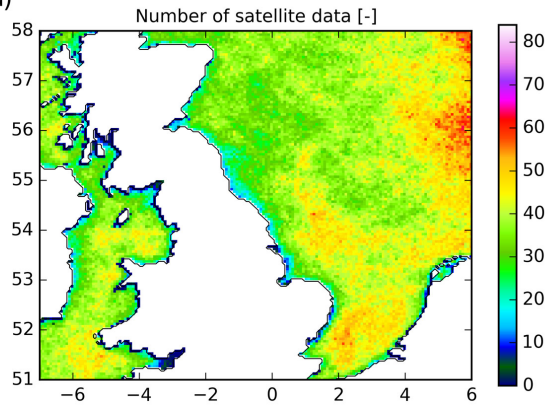

(f)

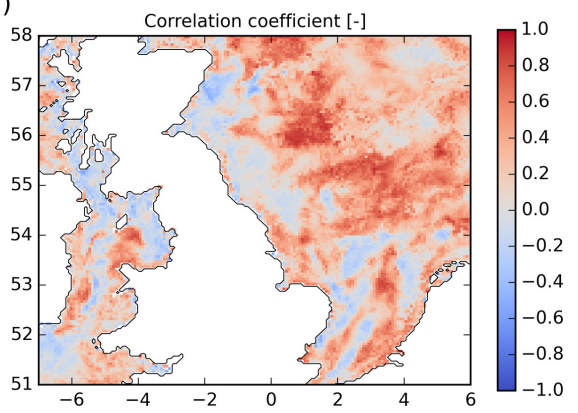

Figure 5. Comparison of summer chlorophyll- $a$ concentrations between model and satellite (April 2008 to September 2008). (a) Model mean; (b) satellite mean; (c) model mean accounting for cloudy days; (d) number of clear days from satellite; (e) relative model bias; (f) correlation coefficient.

runs. For the experimental farms, this was to be expected because of their relatively small size. The north Norfolk farm (Fig. 1, Sites E-G) was located in a dynamic area with high tidal currents and substantial residual circulation, which may account for this result. Hence, in the following, we will focus on the performance of the macroalgae farms.

\subsection{Macroalgae farm performance}

\subsubsection{Strangford Lough}

Modelled winter nutrient concentrations at the Strangford Lough farm site (Fig. 1, Site A; Fig. 9a, b), 1.5$5 \mathrm{mmol} \mathrm{N} \mathrm{m}^{-3}$ and $0.16-0.3 \mathrm{mmol} \mathrm{P} \mathrm{m}^{-3}$, showed substantial variation between years and were lower than expected for a coastal location. Reported values for the Narrows and coastal offshore area for 2009 show values within, but also in exceedance of, these ranges (Kregting et al., 2016). One reason for this could be that nutrient inputs from the largest river entering Strangford Lough, the Quoile River, were not available for inclusion in the model. Summer concentrations were close to zero, with a suggestion that nitrogen was the limiting nutrient. Extinction coefficients (Fig. 9c) ranged from peak winter values of up to $3 \mathrm{~m}^{-1}$ to summer values of 0.2 $0.3 \mathrm{~m}^{-1}$ with fairly similar seasonal patterns per year. Surface irradiance (Fig. 9d) showed a typical and stable seasonal cycle ranging from around $10 \mu \mathrm{mol} \mathrm{m}^{-2} \mathrm{~s}^{-1}$ in winter to maxima of $800 \mu \mathrm{mol} \mathrm{m}^{-2} \mathrm{~s}^{-1}$ in summer. Water temperatures (Fig. 9e) ranged from about $16^{\circ} \mathrm{C}$ in summer to $5-7^{\circ} \mathrm{C}$ in winter, with the winters of 2008-2010 slightly colder than those of 2006-2007. Macroalgae biomass (Fig. 9f) peaked at approximately $0.05 \mathrm{~kg} \mathrm{C} \mathrm{m}^{-1}$ line in all simulated years, about an order of magnitude lower than observed in the 2012-2013 farm deployment (plotted here in 2006). This under-estimation was caused by the low nutrient concentrations, as is also evident in the structure / mass ratio (mass of macroalgae structure over total (structure plus carbohy- 
(a)

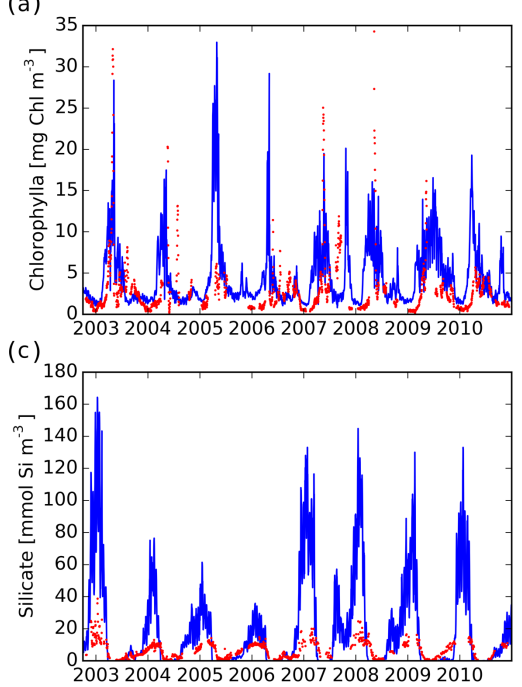

(e)

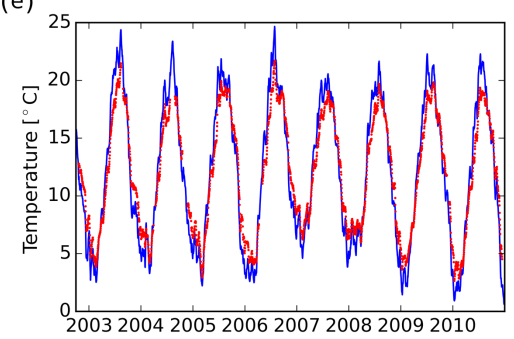

(b)

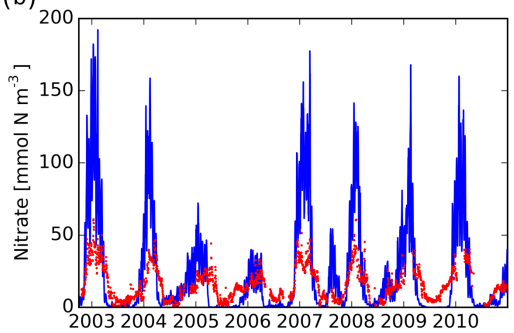

(d)
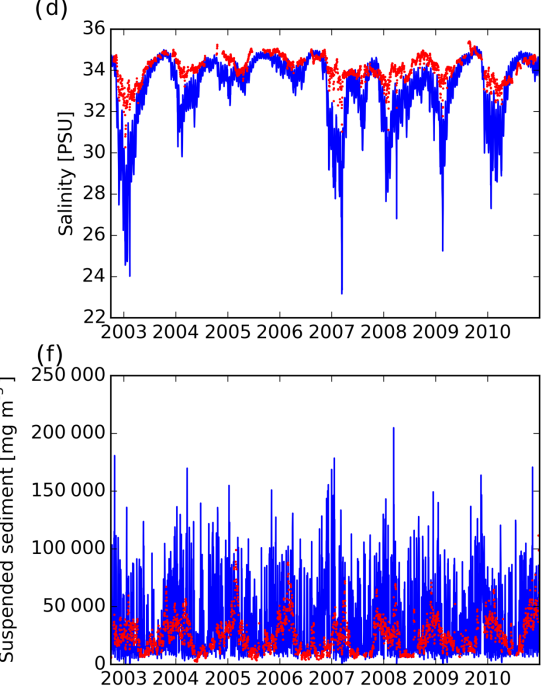

Figure 6. Time series comparison with Warp Anchorage SmartBuoy at the surface. Blue: model; red: observations. (a) Chlorophyll- $a$ concentration; (b) nitrate concentration; (c) silicate concentration; (d) salinity; (e) temperature; (f) suspended sediment concentration.

drates) macroalgae mass; Fig. 9g) and $\mathrm{C} / \mathrm{N}$ and $\mathrm{C} / \mathrm{P}$ ratios (Fig. 9i, j), which show that the modelled macroalgae was high in carbohydrate content from the beginning and then rose throughout the cultivation. Mortality (Fig. 9h) remained low throughout the farming cycles. Nutrient uptake rates per surface area of the farm (Fig. 9k, 1) were close to zero in summer and peaked between $0.05-0.15 \mathrm{mmol} \mathrm{N} \mathrm{m}^{-2}$ day $^{-1}$ and $0.015-0.025 \mathrm{mmol} \mathrm{P} \mathrm{m}^{-2}$ day $^{-1}$.

\subsubsection{Sound of Kerrera and Lynn of Lorne}

For the Sound of Kerrera farm (Fig. 1, Site B; Fig. 10), winter nutrients were higher but also with substantial differences between years $\left(7-15 \mathrm{mmol} \mathrm{N} \mathrm{m}^{-3}\right.$ and $\left.0.6-1.4 \mathrm{mmol} \mathrm{P} \mathrm{m}^{-3}\right)$. This is closer to expected values than at Strangford Lough (Fig. 1, Site A), which is also illustrated by the observations from 2013 to 2014, here plotted for 2010-2011. The model did not reproduce the high summer concentrations evident in the first year of the observations. Extinction coefficients had similar values as in Strangford Lough but with a lower base level in winter. Irradiance was also similar and corresponded well with the monthly mean observed values from 2013-2014. Water temperatures reached up to $18^{\circ} \mathrm{C}$ in summer and $3-6^{\circ} \mathrm{C}$ in winter; ranges were confirmed by the monthly mean observed values from 2013 to 2014. Macroal- gae biomass at harvest showed substantial interannual variability, between 0.11 and $0.48 \mathrm{~kg} \mathrm{C} \mathrm{m}^{-1}$ line. This range corresponds with the observed farm yield of $0.4 \mathrm{~kg} \mathrm{C} \mathrm{m}^{-1}$ line in 2013 and $0.16 \mathrm{~kg} \mathrm{C} \mathrm{m}^{-1}$ line in 2014 and also with the observed yield of $0.6 \mathrm{~kg} \mathrm{C} \mathrm{m}^{-1}$ line for the Strangford Lough farm in 2012/2013. While the observed difference in yield seems to correspond with the observed difference in summer nutrient concentrations, the farm operators also reported heavy biofouling in 2014, which smothered the crop, possibly due to warmer spring temperatures in this particular year. The modelled differences in yield appear to relate to the nitrogen uptake rates. The final modelled carbohydrate content was high. Rates of mortality increased with biomass.

The Lynn of Lorne farm (Fig. 1, Site C; Fig. 11) showed a very similar pattern but achieved almost twice the yields due to higher modelled nutrient concentrations. Interestingly, the carbohydrate content at harvest was lower for the highyield years. In the year with highest yield, mortality shot up 10 -fold shortly before harvest, suggesting that timing of harvesting may be critical. This latter result corresponds with the experience of the farm operators. 

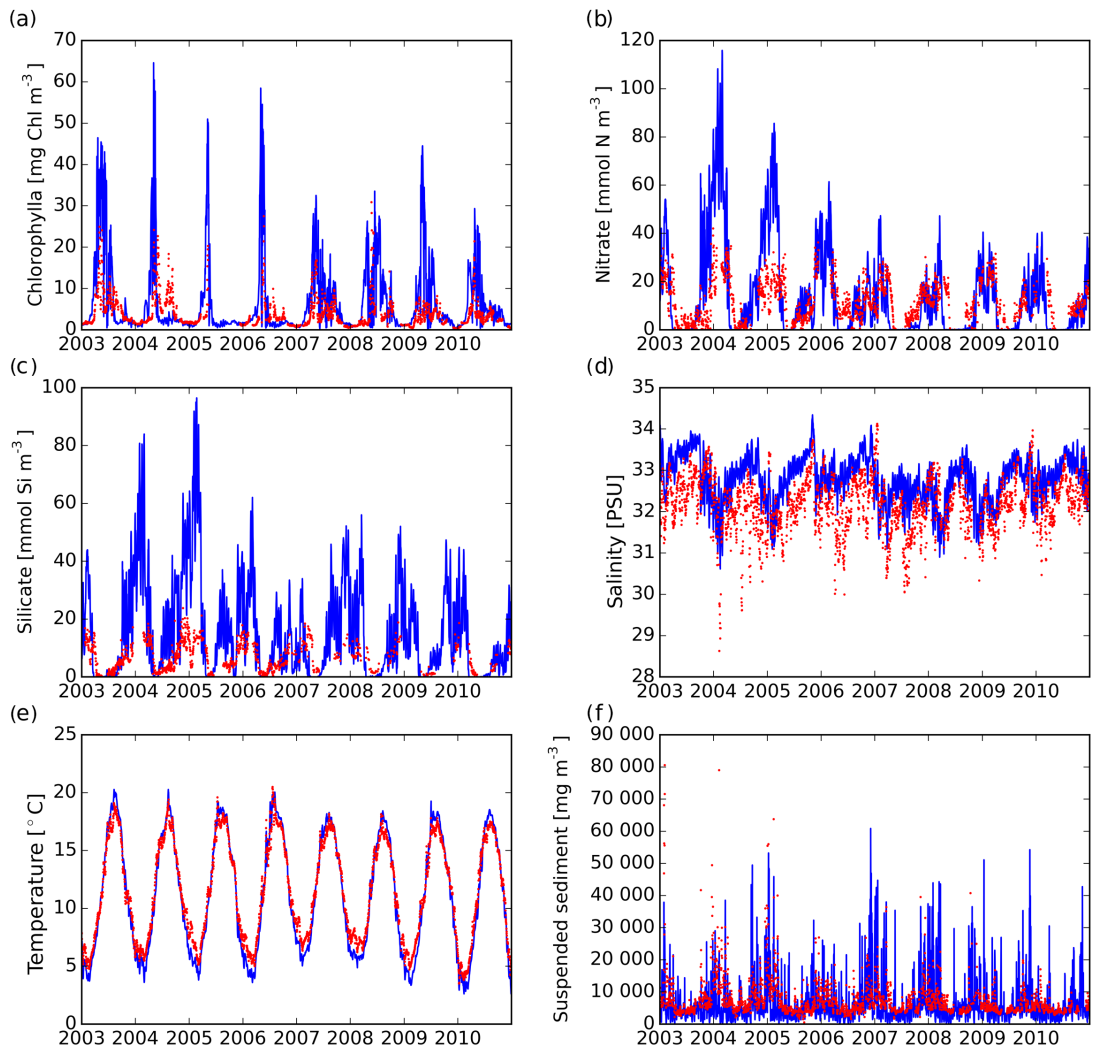

Figure 7. Time series comparison with Liverpool Bay SmartBuoy at the surface. Blue: model; red: observations. (a) Chlorophyll- $a$ concentration; (b) nitrate concentration; (c) silicate concentration; (d) salinity; (e) temperature; (f) suspended sediment concentration.

\subsubsection{Rhine plume experimental farm}

For the Rhine plume farm (Fig. 1, Site D; Fig. 12), the model over-predicted winter nitrate concentrations as compared with observations from the Noordwijk-10 station further to the north by up to a factor of 3 (up to $180 \mathrm{mmol} \mathrm{N} \mathrm{m}^{-3}$ ) and also over-predicted summer concentrations. Phosphate concentrations were reproduced fairly closely, and both model and observations suggest that for a period after the spring bloom, phosphate was the limiting nutrient. The model also reproduced the available observations of the extinction coefficient, which bottomed out at approximately $0.5 \mathrm{~m}^{-1}$, higher than at the Scottish and Irish farm sites. Summer temperatures ranged up to $20^{\circ} \mathrm{C}$, which is near the thermal limit for this kelp species. Farm yields were relatively stable at around $0.7 \mathrm{~kg} \mathrm{C} \mathrm{m}^{-1}$ line, but carbohydrate content remained low as nutrients remained available throughout the summer. The observations suggest that this may not be as extreme in reality. Mortality increased during the later stages of growth, suggesting that if, in reality, the carbohydrate content does increase due to lower nutrient concentrations than in the model, there may be a fine balance in picking the right time to harvest.

\subsubsection{Norfolk hypothetical commercial farm}

The results for the Norfolk hypothetical farm (Fig. 1, Sites EG; Fig. 13) showed winter nitrate concentrations of 40$50 \mathrm{mmol} \mathrm{N} \mathrm{m}^{-3}$ and $1.5-2.5 \mathrm{mmol} \mathrm{P} \mathrm{m}^{-3}$, respectively. This corresponds with observed values of $45-48 \mathrm{mmol} \mathrm{N} \mathrm{m}^{-3}$ and DIN / DIP ratios of 20-30 for the eastern English coast and East Anglia regions in 2001-2005 (Foden et al., 2011). Extinction coefficients were over-estimated by the model by a factor of 3-4. This was compensated for by setting the farm lines to $0.3 \mathrm{~m}$ below the surface instead of $1 \mathrm{~m}$. Summer temperatures ranged up to $20^{\circ} \mathrm{C}$, while winter temperatures could be as low as $2.5^{\circ} \mathrm{C}$. Farm yields were stable and high at approximately $1 \mathrm{~kg} \mathrm{C} \mathrm{m}^{-1}$ line, and the final crop contained substantial concentrations of carbohydrates.

\subsubsection{Predicted farm yields}

In addition to the per unit performance of the farms presented in the previous section, it is, from the point of view of biomass production, useful to list the total predicted yield of the farms at their current size. Total modelled farm yields are summarised in Table 6 for both carbon and wet biomass. In terms of wet biomass, yields were in the range of 2 $3 \mathrm{t} \mathrm{yr}^{-1}$ for the Strangford Lough farm (Fig. 1, Site A), 7- 
(a)

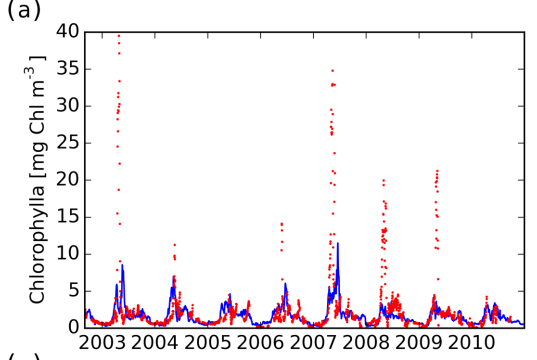

(c)

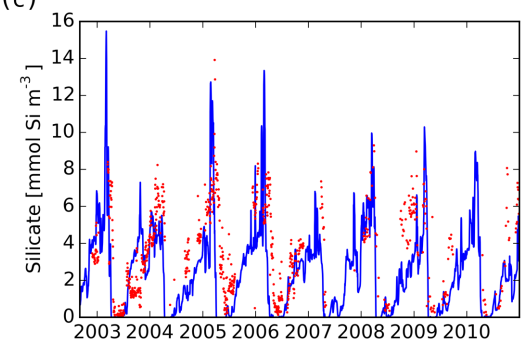

(e)

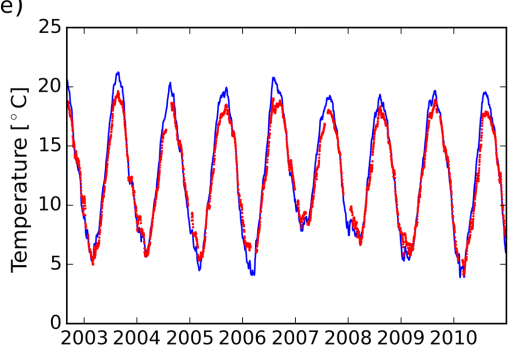

(b)

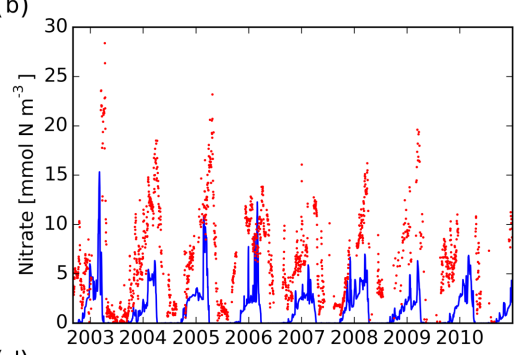

(d)

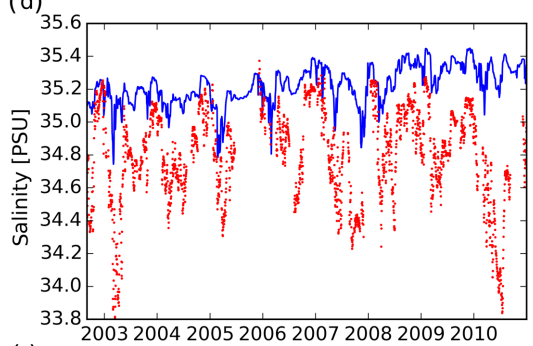

(f)

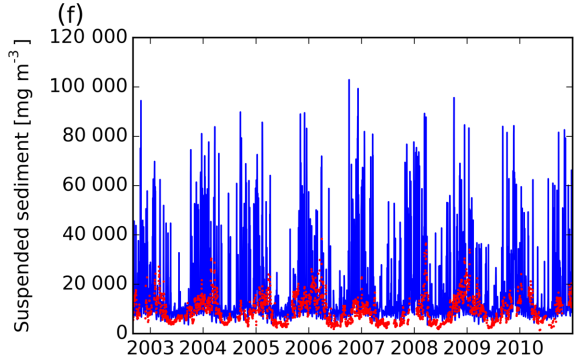

Figure 8. Time series comparison with west Gabbard SmartBuoy at the surface. Blue: model; red: observations. (a) Chlorophyll- $a$ concentration; (b) nitrate concentration; (c) silicate concentration; (d) salinity; (e) temperature; (f) suspended sediment concentration.

Table 6. Simulated farm yields at harvest at the end of July $\left(10^{3} \mathrm{~kg} \mathrm{C} ; 10^{3} \mathrm{~kg}\right.$ wet biomass between brackets; factor of 24.919$)$.

\begin{tabular}{lrrrrrr}
\hline & $\begin{array}{r}\text { Farm size } \\
\text { (per metre of line) }\end{array}$ & $2006 / 2007$ & $2007 / 2008$ & $2008 / 2009$ & $2009 / 2010$ & $2010 / 2011$ \\
\hline Strangford Lough & 2100 & $1.1 \times 10^{-1}(2.8)$ & $1.0 \times 10^{-1}(2.5)$ & $1.1 \times 10^{-1}(2.7)$ & $1.0 \times 10^{-1}(2.5)$ & $8.4 \times 10^{-2}(2.1)$ \\
Sound of Kerrera & 2400 & $9.7 \times 10^{-1}\left(2.4 \times 10^{1}\right)$ & $1.1\left(2.8 \times 10^{1}\right)$ & $7.2 \times 10^{-1}\left(1.8 \times 10^{1}\right)$ & $4.3 \times 10^{-1}\left(1.1 \times 10^{1}\right)$ & $2.8 \times 10^{-1}(7.0)$ \\
Lynn of Lorne & 2400 & $2.3\left(5.6 \times 10^{1}\right)$ & $2.5\left(6.1 \times 10^{1}\right)$ & $1.2\left(3.0 \times 10^{1}\right)$ & $8.1 \times 10^{-1}\left(2.0 \times 10^{1}\right)$ & $7.8 \times 10^{-1}\left(1.9 \times 10^{1}\right)$ \\
Rhine plume & 85 & $6.5 \times 10^{-2}(1.6)$ & $6.0 \times 10^{-2}(1.5)$ & $6.0 \times 10^{-2}(1.5)$ & $5.5 \times 10^{-2}(1.4)$ & $5.9 \times 10^{-2}(1.5)$ \\
Norfolk A & 245000 & $2.4 \times 10^{2}\left(6.0 \times 10^{3}\right)$ & $2.3 \times 10^{2}\left(5.8 \times 10^{3}\right)$ & $2.3 \times 10^{2}\left(58 \times 10^{3}\right)$ & $2.5 \times 10^{2}\left(6.1 \times 10^{3}\right)$ & $2.5 \times 10^{2}\left(6.2 \times 10^{3}\right)$ \\
Norfolk B & 245000 & $2.6 \times 10^{2}\left(6.4 \times 10^{3}\right)$ & $2.5 \times 10^{2}\left(6.2 \times 10^{3}\right)$ & $2.5 \times 10^{2}\left(6.3 \times 10^{3}\right)$ & $2.6 \times 10^{2}\left(6.6 \times 10^{3}\right)$ & $2.7 \times 10^{2}\left(6.7 \times 10^{3}\right)$ \\
Norfolk C & 245000 & $2.7 \times 10^{2}\left(6.6 \times 10^{3}\right)$ & $2.6 \times 10^{2}\left(6.4 \times 10^{3}\right)$ & $2.7 \times 10^{2}\left(6.8 \times 10^{3}\right)$ & $2.8 \times 10^{2}\left(6.9 \times 10^{3}\right)$ & $2.8 \times 10^{2}\left(7.0 \times 10^{3}\right)$ \\
Norfolk total & 735000 & $7.6 \times 10^{2}\left(1.9 \times 10^{4}\right)$ & $7.4 \times 10^{2}\left(1.8 \times 10^{4}\right)$ & $7.8 \times 10^{2}\left(1.9 \times 10^{4}\right)$ & $7.8 \times 10^{2}\left(2.0 \times 10^{4}\right)$ & $7.8 \times 10^{2}\left(2.0 \times 10^{4}\right)$ \\
\hline
\end{tabular}

$30 \mathrm{tyr}^{-1}$ for the Sound of Kerrera farm (Fig. 1, Site B), 20-60 $\mathrm{t} \mathrm{yr}^{-1}$ for the Lynn of Lorne farm (Fig. 1, Site C), around $1.5 \mathrm{t} \mathrm{yr}^{-1}$ for the Rhine plume farm (Fig. 1, Site D) and 18 and $20 \mathrm{kt} \mathrm{yr}^{-1}$ for the combined Norfolk farm (Fig. 1, Sites E-G).

\subsubsection{Variations in farm yield}

The model results suggested that macroalgae growth was dictated by combined availability of nutrients and a sufficient level of light. To illustrate this, nutrient uptake was plotted as a function of irradiance and nutrient concentration. The resulting graphs for nitrogen (Fig. 14) show that this was in- deed the case: the Strangford Lough farm (Fig. 1, Site A; Fig. 14a) experienced low uptake. For the Sound of Kerrera farm (Fig. 1, Site B; Fig. 14b), there was only limited opportunity for higher uptake, as under most conditions either light or nutrients were lacking. For the Rhine plume farm (Fig. 1, Site D; Fig. 14c), very high uptake occurred, starting at high nitrate concentrations in winter, and for light levels over $100 \mu \mathrm{mol} \mathrm{m}^{-2} \mathrm{~s}^{-1}$. The Norfolk farm (Fig. 1, Sites EG; Fig. 14d) experienced a good range of conditions that allowed high nitrate uptake. Results for phosphate showed very similar patterns and are not shown here. 

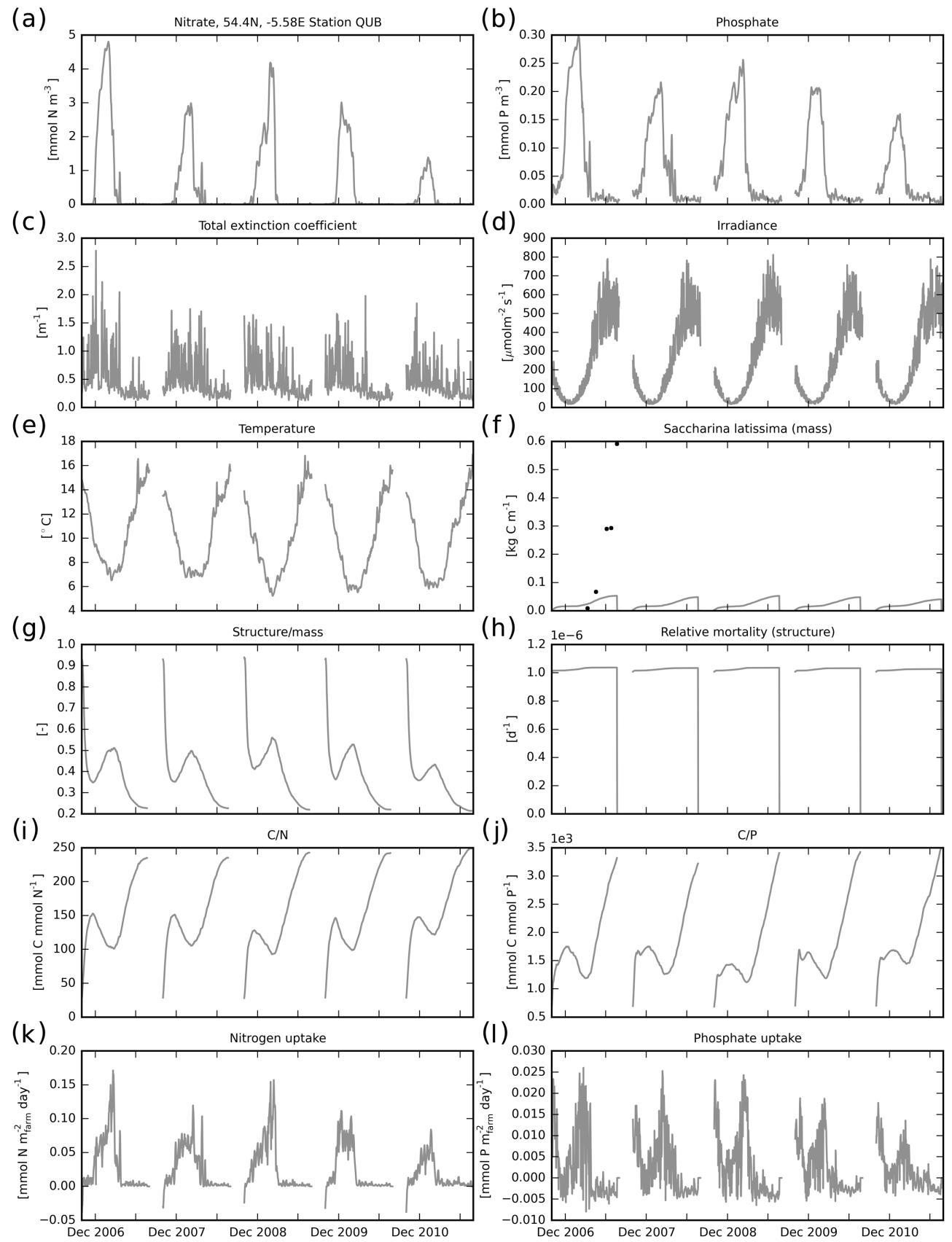

Figure 9. Model results for the Strangford Lough farm site. (a) Surface nitrate concentration; (b) surface phosphate concentration; (c) total extinction coefficient at the surface (excluding contribution by macroalgae); (d) irradiance at the surface; (e) surface water temperature; (f) macroalgae carbon biomass (structure plus carbohydrates) per metre of line; (g) mass of macroalgae structure over total (structure plus carbohydrates) macroalgae mass ratio; (h) relative mortality of macroalgae structure; (i) $\mathrm{C} / \mathrm{N}$ ratio of macroalgae; (j) $\mathrm{C} / \mathrm{P}$ ratio of macroalgae; (k) farm net nitrogen uptake; (l) farm net phosphate uptake. Black dots in panel (f) are observations from the 2012-2013 deployment.

Plotting modelled macroalgae biomass for the Sound of Kerrera farm in a similar way and for the individual years (Fig. 15) elucidates the mechanism behind the variability in farm yield in the model (Fig. 10f). The final biomass appeared to be correlated not only with the winter nutrient concentration but also with structural biomass in spring, when nutrient concentrations were still elevated and light levels exceeded $50 \mu \mathrm{mol} \mathrm{m} \mathrm{m}^{-2} \mathrm{~s}^{-1}$ (compare also with the uptake rates; Fig. 14b). A sufficient level of initial spring biomass was required to allow for sufficient uptake and storage of nutrients to facilitate the early summer growth. The initial spring structural biomass appeared to be correlated with the combination 
(a)

(c)
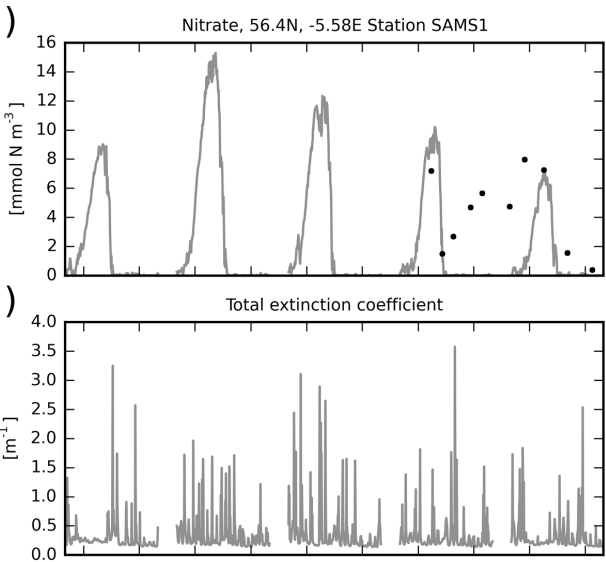

(e)
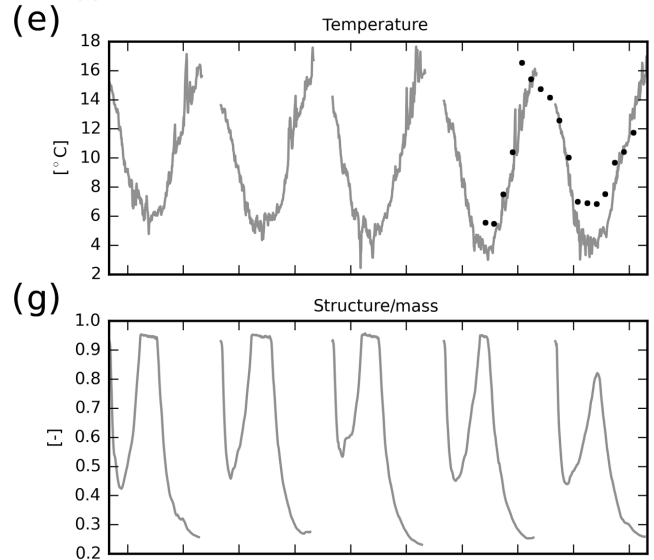

(i)
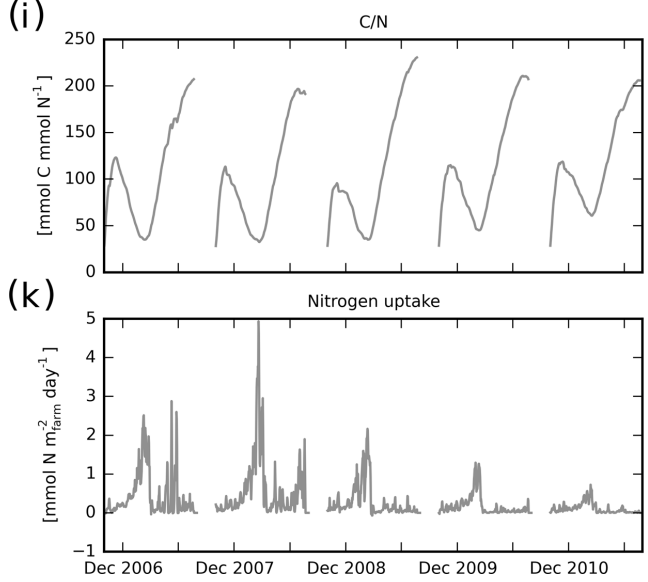

(b)

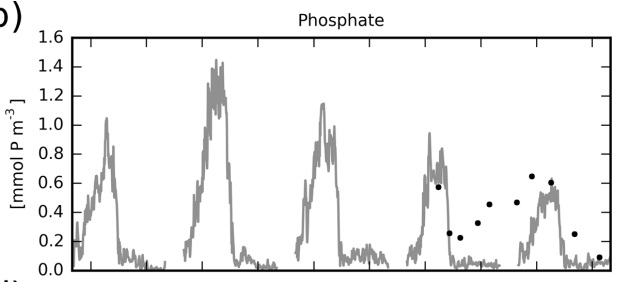

(d)

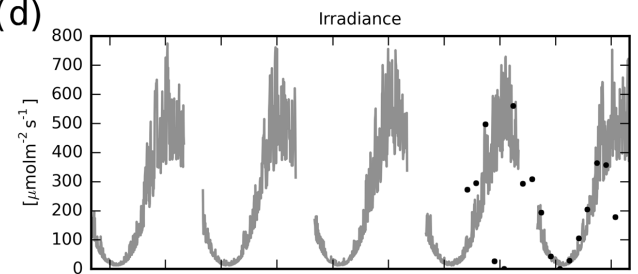

(f)

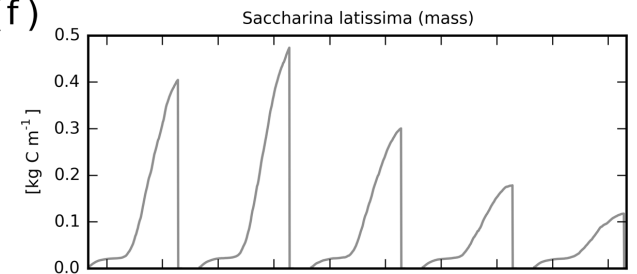

(h)

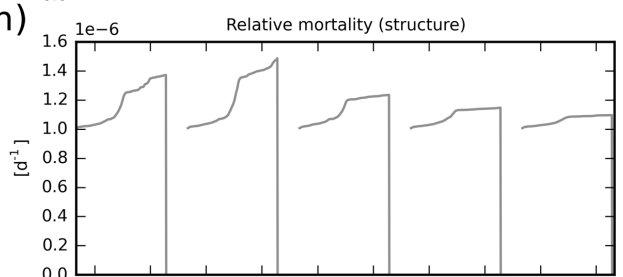

(j)

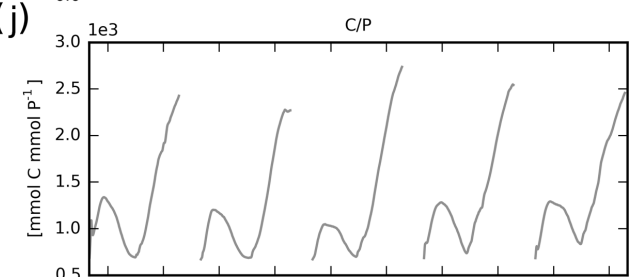

(I)

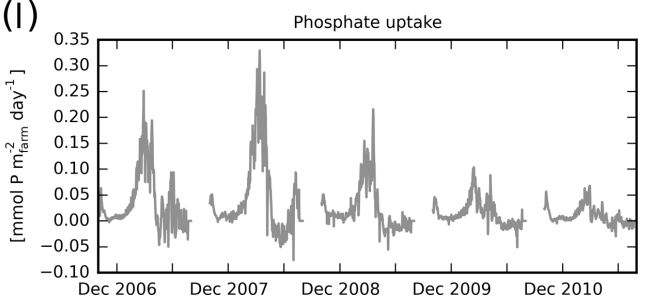

Figure 10. Model results for the Sound of Kerrera farm site. (a) Surface nitrate concentration; (b) surface phosphate concentration; (c) total extinction coefficient at the surface (excluding contribution by macroalgae); (d) irradiance at the surface; (e) surface water temperature; (f) macroalgae carbon biomass per metre of line; (g) mass of macroalgae structure over total macroalgae mass ratio; (h) relative mortality of macroalgae structure; (i) C / N ratio of macroalgae; (j) C / P ratio of macroalgae; (k) farm net nitrogen uptake; (l) farm net phosphate uptake. Black dots are observations: in panels $(\mathbf{a}, \mathbf{b})$ from nutrient samples; in panels $(\mathbf{d}, \mathbf{e})$ monthly averages from a data logger.

of light and nutrient concentrations in late autumn/early winter. Hence, it appears that the timing of the onset of increased nutrient levels and the timing of nutrient drawdown are important determinants of farming success in areas where winter nutrient levels are not elevated and subject to interannual variation.

\section{Discussion}

The modelled production of macroalgae showed a range of responses that may illustrate the actual production that can be expected from commercially operated farms in these locations. Having said this, the model results were not highly accurate for all sites. At Strangford Lough (Fig. 1, Site A), 
(a)

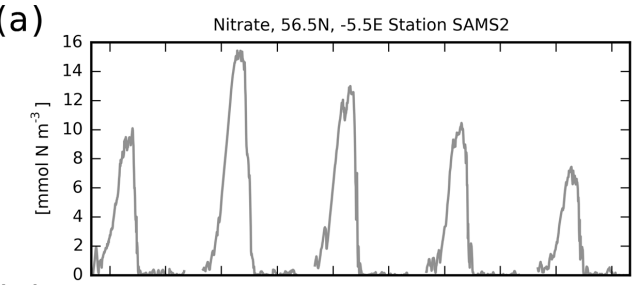

(c)

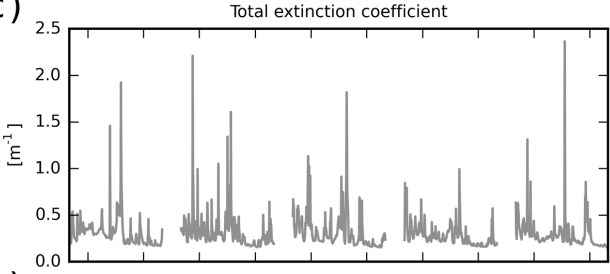

(e)
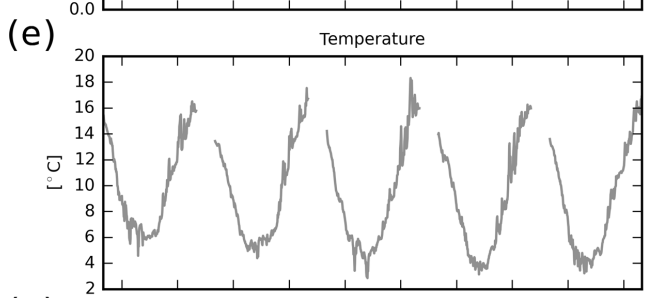

(g)

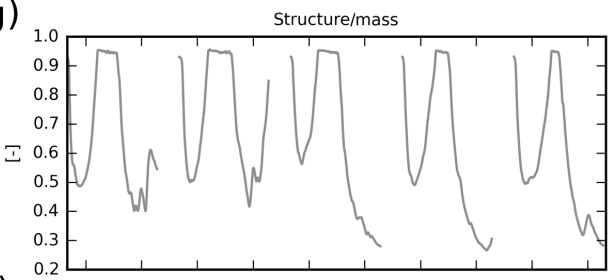

(i)

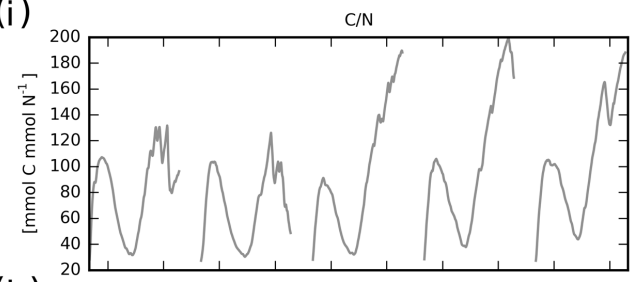

(k)

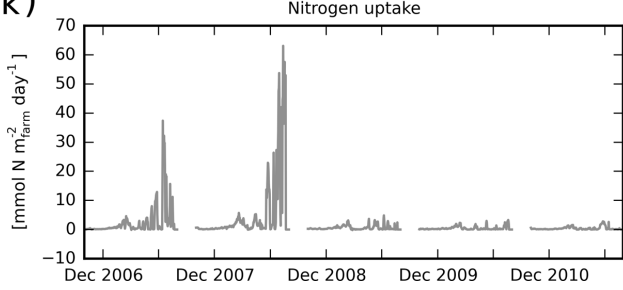

(b)

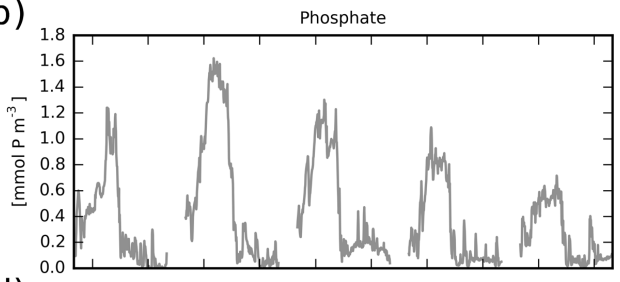

(d)

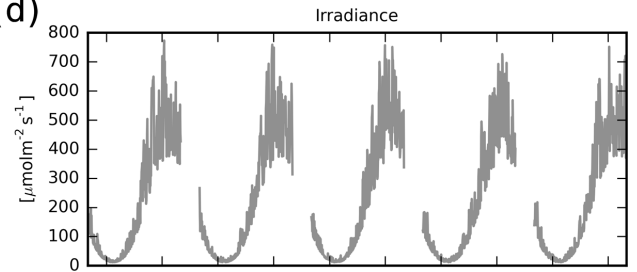

(f)

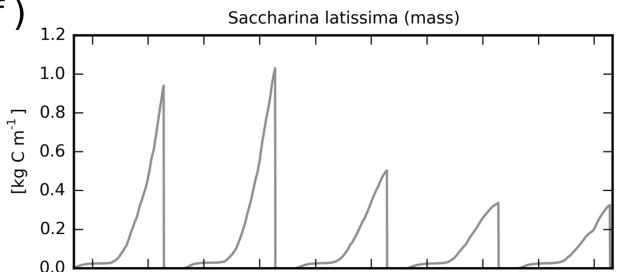

(h)

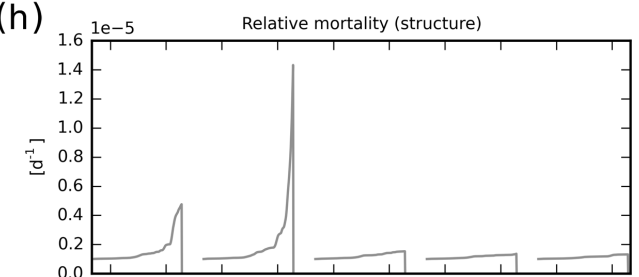

(j)

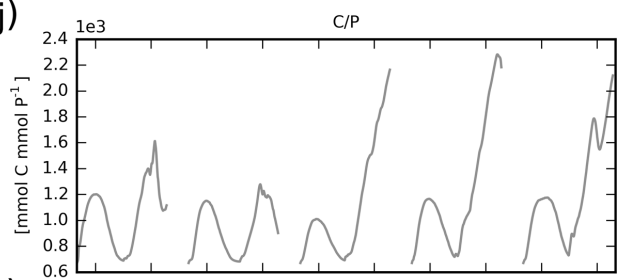

( 1 )

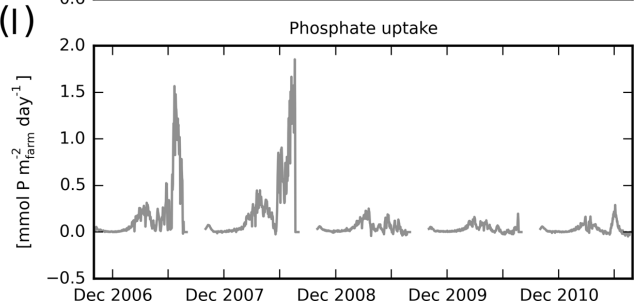

Figure 11. Model results for the Lynn of Lorne farm site. (a) Surface nitrate concentration; (b) surface phosphate concentration; (c) total extinction coefficient at the surface (excluding contribution by macroalgae); (d) irradiance at the surface; (e) surface water temperature; (f) macroalgae carbon biomass per metre of line; (g) mass of macroalgae structure over total macroalgae mass ratio; (h) relative mortality of macroalgae structure; (i) C / N ratio of macroalgae; (j) C / P ratio of macroalgae; (k) farm net nitrogen uptake; (l) farm net phosphate uptake.

the modelled winter nutrient concentrations were likely too low, leading to low macroalgae production in the model. This result provides an analogue for potential lack of farming success at sites with naturally low winter nutrient concentrations.

The model results at the Sound of Kerrera site (Fig. 1, Site B) were realistic, comparing in range with observed win- ter nutrient concentration levels (higher than at the Strangford Lough site) and also comparing in range with the observed variation in macroalgae production. Modelled production at the Lynn of Lorne site (Fig. 1, Site C) was higher than at Sound of Kerrera, coinciding with higher modelled winter nutrient concentrations. However, as a side effect of this, macroalgae carbohydrate content was lower. 

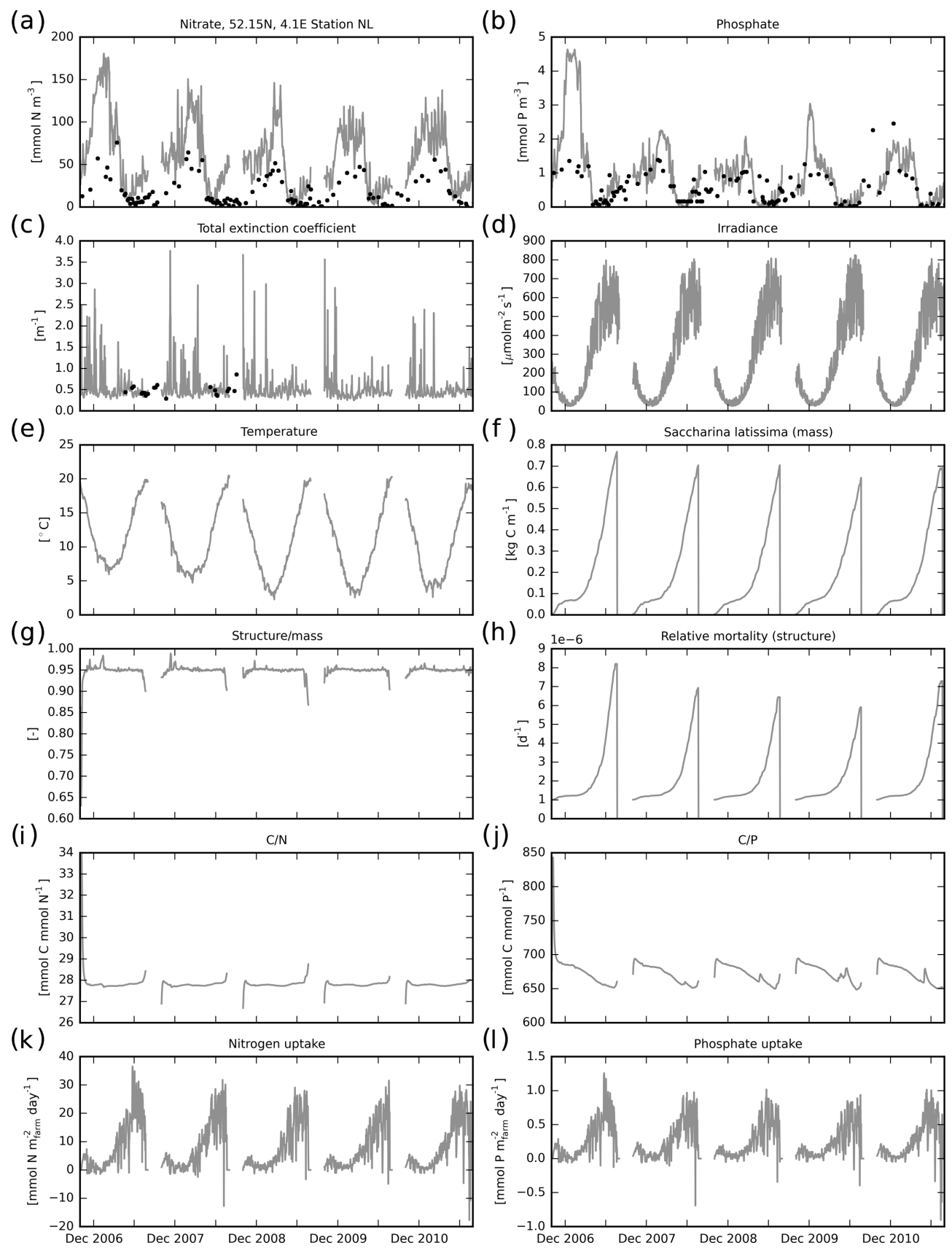

Figure 12. Model results for the Rhine plume farm site. (a) Surface nitrate concentration; (b) surface phosphate concentration; (c) total extinction coefficient at the surface (excluding contribution by macroalgae); (d) irradiance at the surface; (e) surface water temperature; (f) macroalgae carbon biomass per metre of line; (g) mass of macroalgae structure over total macroalgae mass ratio; (h) relative mortality of macroalgae structure; (i) C / N ratio of macroalgae; (j) C / P ratio of macroalgae; (k) farm net nitrogen uptake; (l) farm net phosphate uptake. Black dots are observations from the nearby Noordwijk transect at $10 \mathrm{~km}$ offshore collected by RIKZ (http://live.waterbase.nl).

At the Rhine plume site (Fig. 1, Site D), modelled nitrate levels were substantially higher than observed. Despite this, macroalgae production per metre was higher than at Sound of Kerrera and the last 3 years at Lynn of Lorne despite less favourable light conditions caused by higher concentrations of suspended solids and the line being deeper below the sur- face. This is most likely the result of more favourable nutrient concentrations. The modelled macroalgae contained low concentrations of carbohydrates, as they had continuous access to nutrients. The observed nitrate concentrations at a nearby location suggest limiting conditions in summer, and 

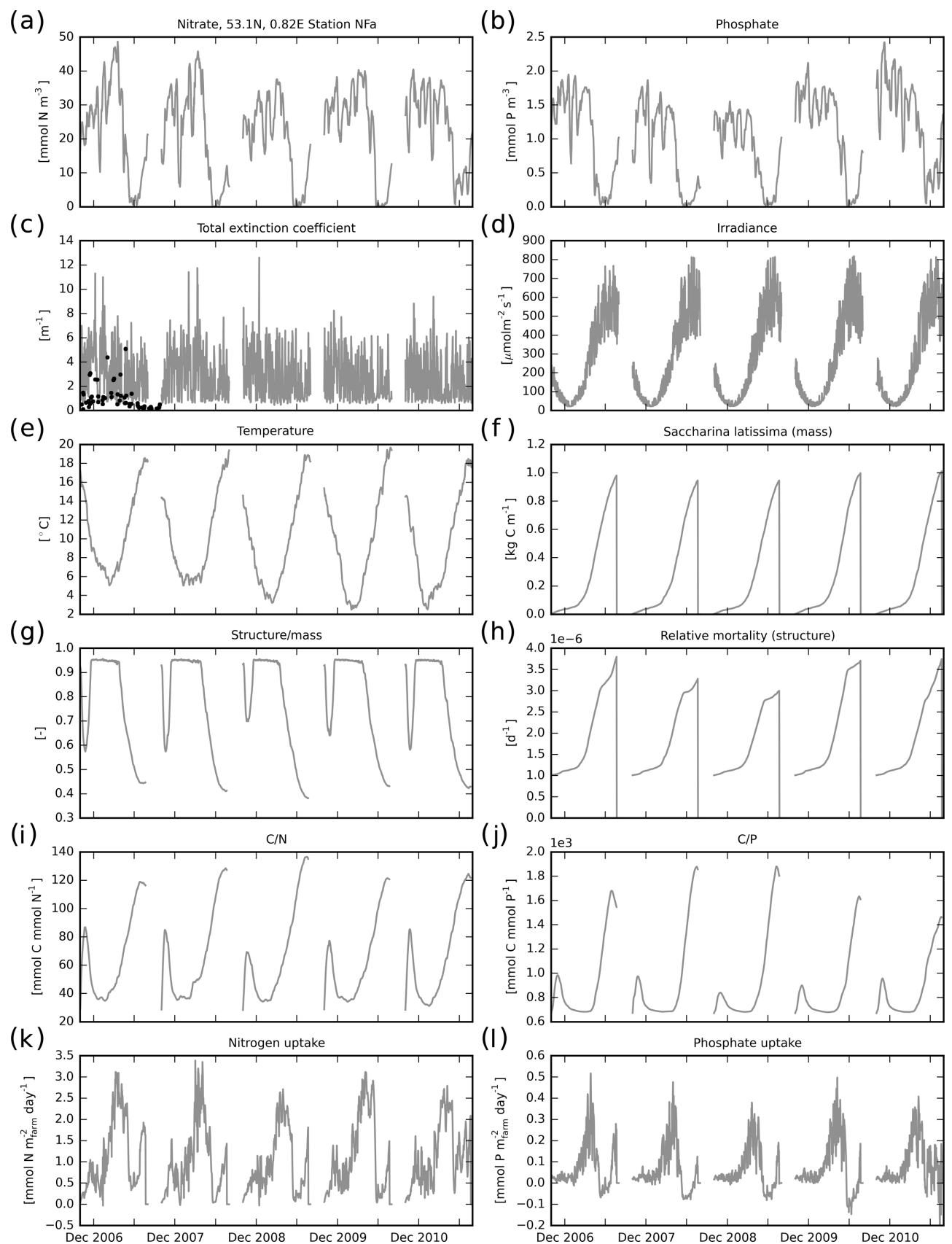

Figure 13. Model results for the western-most grid cell of the north Norfolk farm site. (a) Surface nitrate concentration; (b) surface phosphate concentration; (c) total extinction coefficient at the surface (excluding contribution by macroalgae); (d) irradiance at the surface; (e) surface water temperature; (f) macroalgae carbon biomass per metre of line; (g) mass of macroalgae structure over total macroalgae mass ratio; (h) relative mortality of macroalgae structure; (i) $\mathrm{C} / \mathrm{N}$ ratio of macroalgae; (j) C / P ratio of macroalgae; (k) farm net nitrogen uptake; (l) farm net phosphate uptake. Black dots in panel (c) are the $k_{d}$ contribution by SPM, calculated from in situ SPM samples collected in the years 1996-2000 using the relationship derived by Devlin et al. (2009) and projected onto 2006-2007.

hence the real farm may yield macroalgae with a higher carbohydrate content.

The Norfolk farm (Fig. 1, Sites E-G), after compensating for the over-estimated modelled suspended particulate matter concentrations by reducing the depth of the lines below the surface, produced modelled macroalgae biomass per metre of line higher than those simulated for the Sound of Kerrera farm. This production showed good interannual stability and contained up to $60 \%$ carbohydrates. Simulated winter nutrient concentrations were comparable with observed concen- 


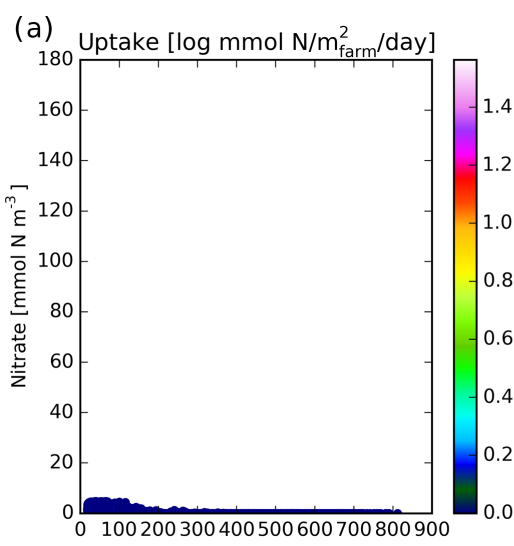

(c)

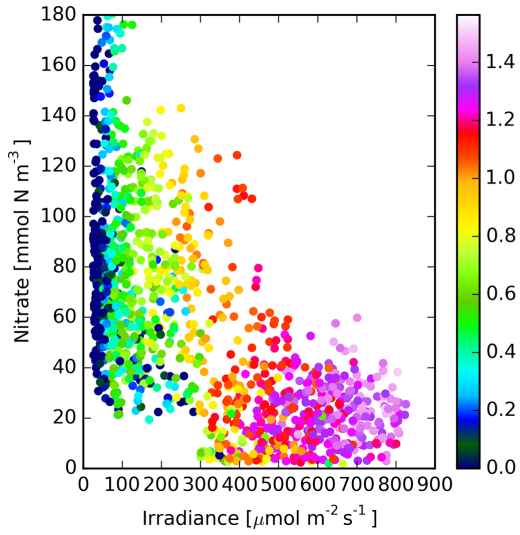

(b)

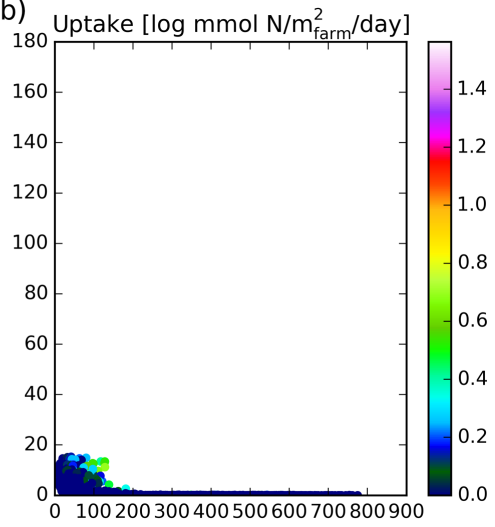

(d)

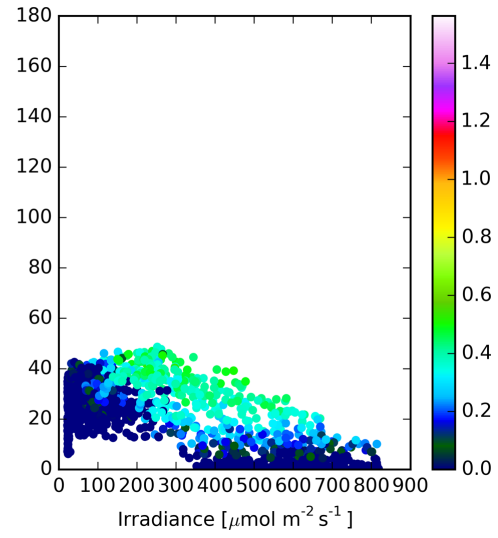

Figure 14. Logarithm of nitrogen uptake as a function of irradiance and nitrate concentrations in the model: (a) Strangford Lough farm, (b) Sound of Kerrera farm, (c) Rhine plume farm and (d) Norfolk farm.

trations. There was a slight variation in macroalgae production between the three model grid cells occupied by the farm, in line with a slight gradient in suspended particulate matter concentrations. Even for this farm, which was the largest that was modelled, we did not find significant changes in temporal averages of other model environmental variables over the period of simulated farming. This is presumably because nutrient requirements of $S$. latissima are very modest, and there is a high level of flushing in the area. Overall, this result supports the potential for this site for macroalgae farming.

The model results suggested that, in areas where winter nutrient levels are modest, farming success could be sensitive to the timing of the autumn onset and spring drawdown of nutrient levels. This result should be further tested and investigated using more detailed field and laboratory observations.

The results of farm yield (Table 6), in relation to farm size, can be used as a first indication of the magnitude of potential carbon removal from the marine environment if farming is scaled up in areas with good farming potential. If the produce is used for biofuel production, the farming activity would result in a related reduction in fossil fuel consumption, when allowing for conversion losses and fuel consump- tion as part of the production cycle. As nutrient-to-carbon ratios were very low, and the model did not detect significant changes in pelagic nutrient concentrations, macroalgae farming would need to happen on a substantially larger scale and/or intensity than simulated here to have an effect on eutrophication.

The current shelf-wide model allows for first assessments of macroalgae farm performance at a wide range of locations on the North-west European Shelf. The relatively coarse model resolution, however, clearly limits the accuracy of the farm production results, in particular in areas with large gradients in topography at scales finer than the model resolution. If more accurate simulations are desired for such locations, or if within-farm gradients in productivity need to be studied, local high-resolution models could be developed that take boundary conditions from the current model. The current model assumes horizontal lines, whereas some experimental farm configurations include vertical or diagonally undulating lines. The Rhine plume farm uses undulating lines, and hence the performance could be different from the simulations presented here. To better represent these different farm configurations and/or investigate potential differences in performance between such configurations, the model could be 


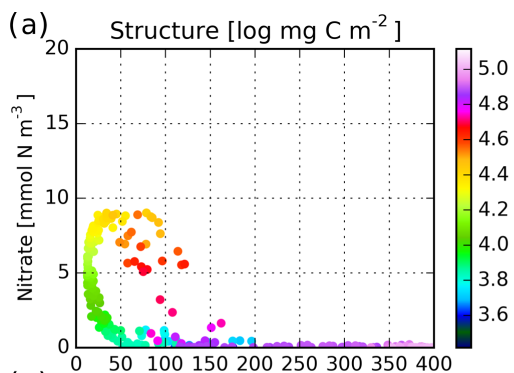

(c)

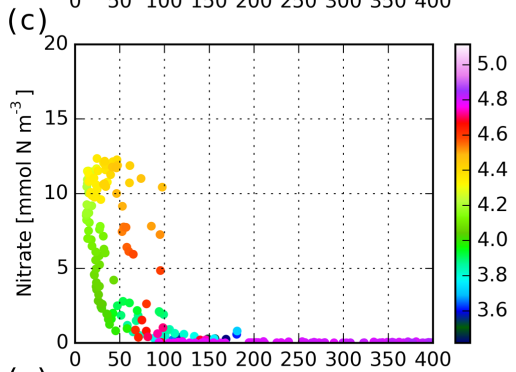

(e)

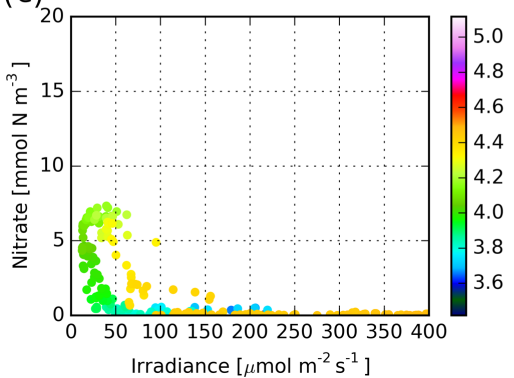

(b) Structure [log $\mathrm{mg} \mathrm{C} \mathrm{m}^{-2}$ ]

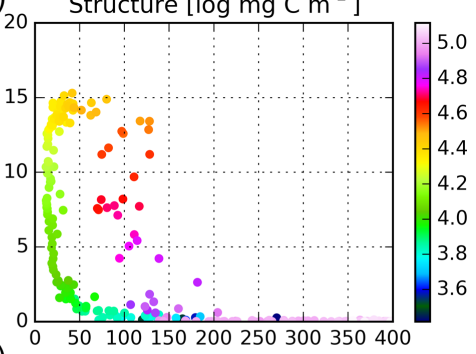

(d)

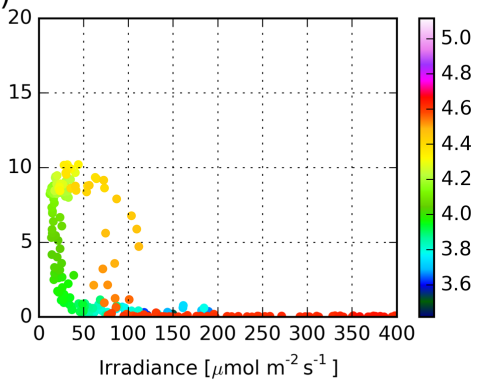

Figure 15. Logarithm of structural biomass as a function of irradiance and nitrate concentrations in the model for the Sound of Kerrera farm: (a) 2006, (b) 2007, (c) 2008, (d) 2009 and (e) 2010.

adapted by introducing the ability to distribute macroalgae biomass in the vertical. Similar adaptations would also be required for the simulation of natural populations, in which plants are anchored to hard substrate and grow vertically towards the surface. The approximation for frond erosion suggested by Broch and Slagstad (2012) does not explicitly include effects of the environment and might be refined with a suitable set of laboratory experiments and field observations. However, the currently simulated values are small, and experience from the experimental farms indicates that higher values only occur later in the season. Crops can be harvested before such mortality occurs, so accurate predictions of mortality are not of high relevance for the current application.

This modelling exercise is a proof of concept and did not aim for a detailed representation of the farm localities, nor did it involve extensive tuning to reproduce detail of farm performance. We used an existing 3-D model setup of the North-west European Shelf (Sect. 2.1), which allowed all farms to be included in one model, albeit with a very coarse representation of coastal geometries. Farm implementation included a level of sub-grid parameterisation. The model was run with forcings for years predating farm deployments, so comparisons with observations collected during the actual deployments can only be qualitative. Despite these limitations, we obtained reasonable confidence in the model, as well as valuable results in terms of farm functioning and performance, macroalgae quality and farming-induced changes in environmental conditions. These predictions are necessary to progress the future development of this fledgling industry.

\section{Recommendations}

This model study did not detect large-scale changes in environmental conditions in the vicinity of the simulated farms. Although this is encouraging, we do not consider this finding to be a generic result, and further and specific investigations should be carried out for specific proposed farm implementations. Such work could include application of and contrasting with other models, and further upscaling of farm size and intensity to explore safe limits. Moreover, the current model (as any model) only captured a subset of environmental processes. Also, simulations with a high-resolution model are recommended to confirm and refine the results obtained here, if further farm implementation plans are developed.

The results for the hypothetical Norfolk farm site (Fig. 1, Sites E-G) suggest favourable conditions for commercial 
macroalgae farming. However, suspended particulate matter concentrations may remain an issue, and accurate regulation of a very shallow depth of line below the surface is probably required. A small-scale field experiment is recommended to test this result in reality.

For the Sound of Kerrera site (Fig. 1, Site B), with lower nutrient concentrations and variable farm yield, the model suggested a relationship between farm yield and autumn and spring nutrient concentrations coinciding with light at sufficient levels. This suggested relationship should be investigated further and confirmed with more detailed observations than available for this study, as further understanding of these processes can help to determine minimum required conditions for successful farming.

The model results suggest high rates of macroalgae growth in early summer, accompanied by an increase in carbohydrate content but also by an increase in mortality. This suggests that there is an optimum window for harvesting, in line with experience from the experimental farms; however, the simulated mortality was not enough to start to reduce biomass. The model suggested differences in this balance between the farm sites, but without further field evidence it is difficult to draw detailed conclusions. It is recommended to continue the field experiments and to gather more detailed information on environmental conditions, carbohydrate content and mortality. This could be accompanied by suitable series of shore-based microcosm experiments. Associated modelling work can help to explain and extrapolate such results.

Concerning the model, improvements could be made in the simulation of nutrients and particulate suspended matter. Also, representations of different farm configurations could be considered (e.g. undulating or vertical lines). Other macroalgae species could be included, as well as a capability to model natural, sea-bed attached macroalgae populations. Finally, inclusion of macroalgae grazers in the model could be investigated, as grazing can be a problem for farm operation.

Data availability. Satellite observations were obtained from the Ifremer ftp server (ftp://ftp.ifremer.fr.:/ifremer/cersat/products/ gridded/ocean-color/atlantic). SmartBuoy data can be obtained through www.cefas.co.uk/cefas-data-hub/smartbuoys/. Observations from the Noordwijk station were obtained from RIKZ (http: //live.waterbase.nl). Other observations can be requested from the authors.

Competing interests. The authors declare that they have no conflict of interest.

Acknowledgements. This work was carried out under the SeaGas project, led by the Centre for Process Innovation (CPI). The SeaGas project is funded by both Innovate UK (for industrial partners) and BBSRC (for academic partners). The funding scheme is the Industrial Biotechnology Catalyst, grant number 102298. Queens University was supported by BBSRC under grant number BB/M028690/1. The work was carried out under Cefas contract code C6627. The macroalgae modules were developed at NIOZ. Recent elements of the model development were funded by Cefas Seedcorn projects DP261 and DP315. Development of postprocessing was supported by Defra under Cefas contract FC002. Claire Coughlan, while at JRC (Ispra), created the open-boundary forcing for temperature, salinity and nutrients for the model. ECMWF and BADC are acknowledged for making the atmospheric forcing available. Data from Strangford Lough are from the EnAlgae project, which was funded by the European Regional Development Fund via the INTERREG IVB NWE programme. Data from the Sound of Kerrera farm were funded through the European Commission Seventh Framework Programme (FP7) project - Advanced Textiles for Open Sea Biomass Cultivation (AT $\sim$ SEA) grant number 280860. The calculations were carried out on the GRACE high-performance cluster of the University of East Anglia. The authors thank two anonymous reviewers and Fabian Große for their extensive comments, which led to substantial improvement of the manuscript.

Edited by: Marilaure Grégoire

Reviewed by: Fabian Große and two anonymous referees

\section{References}

Aldridge, J., van der Molen, J., and Forster, R.: Wider ecological implications of macroalgae cultivation, The Crown Estate, Edinburgh, London, 95 pp., 2012.

Atkinson, M. J. and Smith, S. V.: C:N P ratios of benthic marine plants, Limnol. Oceanogr., 28, 568-574, 1983.

Balmaseda, M. A., Mogensen, K., and Weaver, A.: Evaluation of the ECMWF Ocean Reanalysis ORAS4, Q. J. Roy. Meteor. Soc., 139, 1132-1161, https://doi.org/10.1002/qj.2063, 2013.

Baretta, J. W., Ebenhöh, W., and Ruardij, P.: The European Regional Seas Ecosystem Model, a complex marine ecosystem model, Neth. J. Sea Res., 33, 233-246, 1995.

Baretta-Bekker, J. G., Baretta, J. W., and Ebenhöh, W.: Microbial dynamics in the marine ecosystem model ERSEM II with decoupled carbon assimilation and nutrient uptake, J. Sea Res., 38, 195-211, 1997.

Bartsch, I., Wiencke, C., Bischof, K., Buchholz, C. M., Buck, B. H., Eggert, A., Feuerpfeil, P., Hanelt, D., Jacobsen, S., Karez, R., Karsten, U., Molis, M., Roleda, M. Y., Schubert, H., Schumann, R., Valentin, K., Weinberger, F., and Wiese, J.: The genus Laminaria sensu lato: recent insights and developments, Eur. J. Phycol., 43, 1-86, 2008.

Berrisford, P., Dee, D. P., Poli, P., Brugge, R., Fielding, K., Fuentes, M., Kållberg, P. W., Kobayashi, S., Uppala, S., and Simmons, A.: The ERA-interim archive Version 2.0. ERA Report Series 1, ECMWF, Reading, 23 pp., 2011.

Birkett, D. A., Maggs, C. A., Dring, M. J., Boaden, P. J. S., and Seed, R.: Infralittoral reef biotopes with kelp species (volume VII), An overview of dynamic and sensitivity characteristics for conservation management of marine SACs, Scottish Association of Marine Science (UK Marine SACs Project), 174 pp., 1998. 
Black, W. A. P.: The seasonal variation in weight and chemical composition of the common British Laminariaceae, J. Mar. Biol. Assoc. UK, 29, 45-72, 1950.

Bologna, P. A. X. and Steneck, R. S.: Kelp beds as habitat for American lobster Homarus americanus, Mar. Ecol.-Prog. Ser., 100, 127-134, 1993.

Bolton, J. J. and Lüning, K.: Optimal growth and maximal survival temperatures of Atlantic Laminaria species (Phaeophyta) in culture, Mar. Biol., 66, 89-94, 1982.

Boyd, R. J.: The relation of the plankton to the physical, chemical and biological features of Strangford Lough, Co. Down, P. Roy. Irish. Acad. B, 73, 317-353, 1973.

Bristow, L. A., Jickells, T. D., Weston, K., Marca-Bell, A., Parker, R., and Andrews, J. E.: Tracing estuarine organic matter sources into the southern North Sea using $\mathrm{C}$ and $\mathrm{N}$ isotopic signatures, Biogeochemistry, 113, 9-22, 2013.

Broch, O. J. and Slagstad, D.: Modelling seasonal growth and composition of the kelp Saccharina latissima, J. Appl. Phycol., 24, 759-776, 2012

Buck, B. H. and Buchholz, C. M.: The offshore-ring: a new system design for the open ocean aquaculture of macroalgae, J. Appl. Phycol., 16, 355-368, 2004.

Buck, B. H. and Buchholz, C. M.: Response of offshore cultivated Laminaria saccharina to hydrodynamic forcing in the North Sea, Aquaculture, 250, 674-691, 2005.

Burchard, H. and Bolding, K.: GETM - a general estuarine transport model, Scientific documentation, Tech. Rep. EUR 20253 EN, European Commission, Ispra, Italy, 2002.

Burchard, H., Bolding, K., and Villareal, M. R.: GOTM - a general ocean turbulence model, Theory, applications and test cases, Tech. Rep. EUR 18745 EN, European Commission, 1999.

Burrows, M. T.: Influences of wave fetch, tidal flow and ocean colour on subtidal rocky communities, Mar. Ecol.-Prog. Ser., 445, 193-207, 2012.

Capuzzo, E., Stephens, D., Aldridge, J., and Forster, R. M.: Feasibility study - Potential locations for macro-algae farming off the East Anglian coast, The Crown Estate, 37 pp., available at: www.thecrownestate.co.uk/media/389748/eipotential-locations-for-macro-algae-farming-off-the-coast-ofeast-anglia.pdf (last access: 19 February 2018), 2014

Chapman, A. R. O., Markham, J. W., and Lüning, K.: Effects of nitrate concentration on the growth and physiology of Laminaria saccharina (Phaeophyta) in culture, J. Phycol., 14, 195198, 1978.

Chopin, T., Buschmann, A. H., Halling, C., Troell, M., Kautsky, N., Neori, A., Kraemer, G. P., Zertuche-Gonzalez, J., Yarish, C., and Neefus, C.: Integrating seaweeds into marine aquaculture systems: a key toward sustainability, J. Phycol., 37, 975-986, 2001.

Connolly, N. J. and Drew, E. A.: Physiology of Laminaria III. Effect of a coastal eutrophication gradient on seasonal patterns of growth and tissue composition in $L$. digitata LAMOUR and $L$. saccharina (L.) LAMOUR, Mar. Ecol., 6, 181-195, 1985.

Daly, B. and Konar, B.: Effects of macroalgal structural complexity on nearshore larval and post-larval crab composition, Mar. Biol., 153, 1055-1064, 2008.

Dee, D. P., Uppala, S. M., Simmons, A. J., Berrisford, P., Poli, P., Kobayashi, S., Andrae, U., Balmaseda, M. A., Balsamo, G., Bauer, P., Bechtold, P., Beljaars, A. C. M., van de Berg, L., Bidlot, J., Bormann, N., Delsol, C., Dragani, R., Fuentes, M., Geer,
A. J., Haimberger, L., Healy, S. B., Hersbach, H., Hólm, E. V., Isaken, L., Kållberg, P. W., Köhler, M., Matricardi, M., McNalli, A. P., Monge-Sanz, B. M., Morcrette, J. J., Park, B. K., Peubey, C., de Rosnay, P., Tavolato, C., Thépaut, J. N., and Vitart, F.: The ERA-interim reanalysis: configuration and performance of the data assimilation system, Q. J. Roy. Meteor. Soc., 137, 553-597, 2011.

De Ruyter, W. P. M., Visser, A. W., and Bos, W. G.: The Rhine outflow: a prototypical pulsed discharge plume in a high energy shallow sea, J. Marine Syst., 12, 263-276, 1997.

Devlin, M. J., Barry, J., Mills, D. K., Gowen, R. J., Foden, J., Sivyer, D., Greenwood, N., Pearce, D., and Tett, P.: Estimating the diffuse attenuation coefficient from optically active constituents in UK marine waters, Est. Coast. Shelf S., 82, 73-83, 2009.

Droop, M. R.: Some thoughts on nutrient limitation in algae, J. Phycol., 9, 264-272, 1973.

Droop, M. R.: The nutrient status of algal cells in continuous culture, J. Mar. Biol. Assoc. UK, 54, 825-855, 1974.

Duarte, C. M.: Nutrient Concentration in aquatic plants, Limnol. Oceangr., 37, 882-889, 1992.

Duarte, C., Wu, J., Xiao, X., Bruhn, A., and Krause-Jensen, D.: Can seaweed farming play a role in climate change mitigation and adaptation?, Front. Mar. Sci., 4, 100, https://doi.org/10.3389/fmars.2017.00100, 2017.

Dyer, K. R. and Moffat, T. J.: Fluxes of suspended matter in the East Anglian plume Southern North Sea, Cont. Shelf Res., 18, 1311-1331, 1998.

Eckman, J. E., Duggins, D. O., and Sewell, A. T.: Ecology of under story kelp environments. I. Effects of kelps on flow and particle transport near the bottom, J. Exp. Mar. Biol. Ecol., 129, 173-187, 1989.

Engel, A.: The role of transparent exopolymer particles (TEP) in the increase in apparent particle stickiness $(\alpha)$ during the decline of a diatom bloom, J. Plankton Res., 22, 485-497, 2000.

FAO: The State of the World Fisheries and Aquaculture, Opportunities and challenges, Food and Agriculture Organization of the United Nations, Rome, 2014.

Fei, X.: Solving the coastal eutrophication problem by large scale seaweed cultivation, Hydrobiologia, 512, 145-151, 2004

Fernand, F., Israel, A., Skjermo, J., Wickard, T., Timmermans, K. R., and Golberg, A.: Offshore macroalgae biomass for bioenergy production: Environmental aspects, technological achievements and challenges, Renew. Sust. Energ. Rev., 75, 35-45, https://doi.org/10.1016/j.rser.2016.10.046, 2017.

Foden, J., Devlin, M. J., Mills, D. K., and Malcolm, S. J.: Searching for undesirable disturbance: an application of the OSPAR eutrophication assessment method to marine waters of England and Wales, Biogeochemistry, 106, 157-175, https://doi.org/10.1007/s10533-010-9475-9, 2011.

Fredriksen, S.: Food web studies in a Norwegian kelp forest based on stable isotope $\left(\delta^{13} \mathrm{C}\right.$ and $\left.\delta^{15} \mathrm{~N}\right)$ analysis, Mar. Ecol. Ser., 260, 71-81, 2003.

Garcia, H. E., Locarnini, R. A., Boyer, T. P., Antonov, J. I., Zweng, M. M., Baranova, O. K., and Johnson, D. R.: World Ocean Atlas 2009, Volume 4: Nutrients (phosphate, nitrate, silicate), edited by: Levitus, S., NOAA Atlas NESDIS 71, US Government Printing Office, Washington, D.C., 398 pp., 2010.

Gaylord, B. P., Rosman, J. H., Reed, D. C., Koseff, J. R., Fram, J., MacIntyre, S., Arkema, K., McDonald, C., Brzezinski, M. A., 
Largier, J. L., Monismith, S. G., Raimondi, P. T., and Mardian, B.: Spatial patterns of flow and their modification within and around a giant kelp forest, Limnol. Oceanogr., 52, 1838-1852, 2007.

Gévaert, F., Davoult, D., Creach, A., Kling, R., Janquin, M.-A., Seuront, L., and Lemoine, Y.: Carbon and nitrogen content of Laminaria saccharina in the eastern English Channel: biometrics and seasonal variations, J. Mar. Biol. Assoc. UK, 81, 727-734, 2001.

Gohin, F.: Annual cycles of chlorophyll- $a$, non-algal suspended particulate matter, and turbidity observed from space and in-situ in coastal waters, Ocean Sci., 7, 705-732, https://doi.org/10.5194/os-7-705-2011, 2011.

Gohin, F., Loyer, S., Lunven, M., Labry, C., Froidefond, J. M., Delmas, D., Huret, M., and Herbland, A.: Satellite-derived parameters for biological modelling in coastal waters: Illustration over the eastern continental shelf of the Bay of Biscay, Remote Sens. Environ., 95, 29-46, 2005.

Gowen, R. J., Tett, P., Kennington, K., Mills, D. K., Shammon, T. M., Stewart, B. M., Greenwood, N., Flanagan, C., Devlin, M., and Wither, A.: The Irish Sea: Is it eutrophic?, Estuar. Coast. Shelf S., 76, 239-254, 2008.

Greenwood, N., Parker, E. R., Fernand, L., Sivyer, D. B., Weston, K., Painting, S. J., Kröger, S., Forster, R. M., Lees, H. E., Mills, D. K., and Laane, R. W. P. M.: Detection of low bottom water oxygen concentrations in the North Sea; implications for monitoring and assessment of ecosystem health, Biogeosciences, 7, 1357-1373, https://doi.org/10.5194/bg-7-1357-2010, 2010.

Hartney, K. B.: Site fidelity and homing behaviour of some kelp-bed fishes, J. Fish Biol., 49, 1062-1069, 1996.

He, P., Xu, S., Zhang, H., Wen, S., Dai, Y., Lin, S., and Yarish, C.: Bioremediation efficiency in the removal of dissolved inorganic nutrients by the red seaweed, Porphyra yezoensis, cultivated in the open sea, Water Res., 42, 1281-1289, 2008.

Hughes, A., Kelly, M. S., Black, K. D., and Stanley, M. S.: Biogas from macroalgae: is it time to revisit the idea?, Biotechnol. Biofuels, 5, 86, https://doi.org/10.1186/1754-6834-5-86, 2012.

Hydes, D., Kelly-Gerreyn, B., Le Gall, A., and Proctor, R.: The balance of supply of nutrients and demands of biological production and denitrification in a temperate latitude shelf sea - a treatment of the southern North Sea as an extended estuary, Mar. Chem., 68, 117-131, 1999.

Jackson, G. A.: Currents in the high drag environment of a coastal kelp stand off California, Cont. Shelf Res., 17, 1913-1928, 1997.

Kain, J. M.: Aspects of the biology of Laminaria hyperborea II. Age, weight and lenght, J. Mar. Biol. Assoc. UK, 43, 129-151, 1963.

Kain, J. M.: A view of the genus Laminaria, Ann. Rev. Oceanogr. Mar. Biol., 17, 101-161, 1979.

Kang, C. K., Choy, E. J., Son, Y., Lee, J. Y., Kim, J. K., Kim, Y., and Lee, K. S. L.: Food web structure of a restored macroalgal bed in the eastern Korean peninsula determined by $\mathrm{C}$ and $\mathrm{N}$ stable isotope analyses, Mar. Biol., 153, 1181-1198, 2008.

Kerrison, P. D., Stanley, M. S., Edwards, M. D., Black, K. D., and Hughes, A. D.: The cultivation of European kelp for bioenergy: Site and species selection, Biomass Bioenerg., 80, 229242, 2015.

Kraan, S.: Mass-cultivation of carbohydrate rich macroalgae, a possible solution for sustainable biofuel production, Mitig. Adapt.
Strat. Gl., 18, 27-46, https://doi.org/10.1007/s11027-010-92755, 2013.

Kregting, L. T. and Elsäßer, B.: A hydrodynamic modelling framework for Strangford Lough part 1: tidal model, J. Mar. Sci. Eng., 2, 46-65, https://doi.org/10.3390/jmse2010046, 2014.

Kregting, L. T., Blight, A., Elsäßer, B., and Savidge, G.: The influence of water motion on the growth rate of the kelp Laminaria hyperborea, J. Exp. Mar. Biol. Ecol., 448, 337-345, https://doi.org/10.1016/j.jembe.2013.07.017, 2014.

Kregting, L. T., Blight, A., Elsäßer, B., and Savidge, G.: The influence of water motion on the growth rate of the kelp Laminaria digitata, J. Exp. Mar. Biol. Ecol., 478, 86-95, https://doi.org/10.1016/j.jembe.2016.02.006, 2016.

Laane, R. W. P. M.: Applying the critical load concept to the nitrogen load of the river Rhine to the Dutch coastal zone, Estuar. Coast. Shelf S., 62, 487-493, 2005.

Le Provost, C., Lyard, F., Genco, M. L., and Rabilloud, F.: A hydrodynamic ocean tide model improved by assimilation of a satellite altimeter-derived data set, J. Geophys. Res., 103, 5513-5529, 1998.

Lenhart, H. J., Mills, D. K., Baretta-Bekker, H., van Leeuwen, S. M., van der Molen, J., Baretta, J. W., Blaas, M., Desmit, X., Kühn, W., Lacroix, G., Los, H. J., Ménesguen, A., Neves, R., Proctor, R., Ruardij, P., Skogen, M. D., Vanhoutte-Grunier, A., Villars, M. T., and Wakelin, S. L.: Predicting the consequences of nutrient reduction on the eutrophication status of the North Sea, J. Marine Syst., 81, 148-170, 2010.

Lobban, C. S. and Harrison, P. J.: Seaweed ecology and physiology, Cambridge University Press, Cambridge, 366 pp., 1997.

Lüning, K. and Pang, S.: Mass cultivation of seaweed: current aspects and approaches, J. App. Phycol., 15, 115-119, 2003.

Mills, D. K., Greenwood, N., Kröger, S., Devlin, M., Sivyer, D. B., Pearce, D., Cutchey, S., and Malcolm, S. J.: New approaches to improve the detection of eutrophication in UK coastal waters, Env. Res. Eng. Manag., 2, 36-42, 2005.

Mogensen, K., Alonso Balmaseda, M., and Weaver, A.: The NEMOVAR ocean data assimilation system as implemented in the ECMWF ocean analysis for System4, ECMWF Thechnical Memorandum 668, Toulouse, France, 59 pp., 2012.

Mooney-McAuley, K. M., Edwards, M. D., Champenois J., and Gorman, E.: Best Practice Guidelines for Seaweed Cultivation and Analysis, Public Output report of the EnAlgae project, Swansea, 2016.

Nellemann, C., Corcoran, E., Duarte, C. M., Valdes, L., De Young, C., Fonseca, L., and Grimsditch, G. (Eds.): Blue Carbon. A rapid response assessment, United Nations Environment Programme, GRID-Arendal, available at: www.grida.no, Birkeland Trykkeri AS, Norway, 90 pp., 2009.

Parke, P.: Studies on British Laminariaceae. I. Growth in Laminaria saccharina (L.) LAMOUR, J. Mar. Biol. Assoc. UK, 27, 651709, 1948.

Peperzak, L., Colijn, F., Gieskes, W. W. C., and Peeters, J. C. H.: Development of the diatom-Phaeocystis spring bloom in the Dutch coastal zone of the North Sea: the silicon depletion versus the daily irradiance threshold hypothesis, J. Plankton Res., 20, 517-537, 1998.

Peteiro, C., Salinas, J. M., Freire, O., and Fuertes, C.: Cultivation of the autochtonous seaweed Laminaria saccharina off the Galician 
coast (NW Spain): production and features of the sporophytes for an annual and biennial harvest, Thalassas, 22, 45-53, 2006.

Pietrzak, J. D., de Boer, G. J., and Eleveld, M. A.: Mechanisms controlling the intra-annual mesoscale variability of SST and SPM in the southern North Sea, Cont. Shelf Res., 31, 594-610, 2011.

Proctor, R., Holt, J. T., Allen, J. I., and Blackford, J.: Nutrient fluxes and budgets for the North West European Shelf from a three-dimensional model, Sci. Total Environ., 314-316, 769785, 2003.

Ruardij, P. and van Raaphorst, W.: Benthic nutrient regeneration in the ERSEM-BFM ecosystem model of the North Sea, Neth. J. Sea Res., 33, 453-483, 1995.

Ruardij, P., van Haren, H., and Ridderinkhof, H.: The impact of thermal stratification on phytoplankton and nutrient dynamics in shelf seas: a model study, J. Sea Res., 38, 311-331, 1997.

Ruardij, P., Veldhuis, M. J. W., and Brussaard, C. P. D.: Modeling the bloom dynamics of the polymorphic phytoplankter Phaeocystis globosa: impact of grazers and viruses, Harmful Algae, 4, 941-963, 2005.

Sanderson, J. C., Dring, M. J., Davidson, K., and Kelly, M. S.: Culture, yield and bioremediation potential of Palmaria palmata (Linnaeus) Weber \& Mohr and Saccharina latissima (Linnaeus) C.E. Lane, C. Mayes, Druehl \& G.W. Saunders adjacent to fish farm cages in northwest Scotland, Aquaculture, 354-355, 128$135,2012$.

Schiener, P., Zhao, S., Theodoridou, K., Carey, M., MooneyMcAuley, K., and Greenwell, Chr.: The nutritional aspects of biorefined Saccharina latissima, Ascophyllum nodosum and Palmaria palmata, Biomass Conv. Bior., 7, 221-235, https://doi.org/10.1007/s13399-016-0227-5, 2017.

Sjøtun, K.: Seasonal lamina growth in two age groups of Laminaria saccharina (L.) Lamour in Western Norway, Bot. Mar., 36, 433441, 1993.

Smale, D. A., Burrows, M. T., Moore, P., O'Connor, N., and Hawkins, S. J.: Threats and knowledge gaps for ecosystem services provided by kelp forests: a northeast Atlantic perspective, Ecol. Evol., 11, 4016-4038, https://doi.org/10.1002/ece3.774, 2013.

Smith, F.: An Assessment of the Water Balance of the Strangford Lough Catchment (Belfast Thesis Master in Science) School of Planning, Architecture \& Civil Engineering, Queen's University Belfast, 2010.

Smyth, D., Kregting, L., Elsäßer, B., Kennedy, R., and Roberts, D.: Using particle dispersal models to assist in the conservation and recovery of the overexploited native oyster (Ostrea edulis) in an enclosed sea lough, J. Sea Res., 108, 50-59, 2016.

Taylor, J. and Service, M.: The Trophic Status of Strangford Lough, Department of Agriculture of Northern Ireland, Belfast, 1997.

Troost, T. A., de Kluijver, A., and Los, F. J.: Evaluation of eutrophication variables and thresholds in the Dutch North Sea in a historical context - A model analysis, J. Marine Syst., 134, 45-56, 2014.

Van der Burg, S. W. K., van Duijn, A. P., Bartelings, H., van Krimpen, M. M., and Poelman, M.: The economic feasibility of seaweed production in the North Sea, Aquacult. Econ. Manag., 203, 235-252, 2016.
Van der Hout, C. M., Gerkema, Th., Nauw, J. J., and Ridderinkhof, H.: Observations of a narrow zone of high suspended particulate matter (SPM) concentrations along the Dutch coast, Cont. Shelf Res., 95, 27-38, 2015.

Van der Molen, J., Aldridge, J. N., Coughlan, C., Parker, E. R., Stephens, D., and Ruardij, P.: Modelling marine ecosystem response to climate change and trawling in the North Sea, Biogeochemistry, 113, 213-236, https://doi.org/10.1007/s10533-0129763-7, 2013.

Van der Molen, J., Smith, H. C. M., Lepper, P., Limpenny, S., and Rees, J.: Predicting the large-scale consequences of offshore wind array development on a North Sea ecosystem, Cont. Shelf Res., 85, 60-72, https://doi.org/10.1016/j.csr.2014.05.018, 2014.

Van der Molen, J., Ruardij, P., and Greenwood, N.: Potential environmental impact of tidal energy extraction in the Pentland Firth at large spatial scales: results of a biogeochemical model, Biogeosciences, 13, 2593-2609, https://doi.org/10.5194/bg-132593-2016, 2016.

Van der Molen, J., Ruardij, P., and Greenwood, N.: A 3D SPM model for biogeochemical modelling, with application to the northwest European continental shelf, J. Sea Res., 127, 63-81, https://doi.org/10.1016/j.seares.2016.12.003, 2017.

Vichi, M., Oddo, P., Zavatarelli, M., Coluccelli, A., Coppini, G., Celio, M., Fonda Umani, S., and Pinardi, N.: Calibration and validation of a one-dimensional complex marine biogeochemical flux model in different areas of the northern Adriatic shelf, Ann. Geophys., 21, 413-436, https://doi.org/10.5194/angeo-21-413-2003, 2003.

Vichi, M., Ruardij, P., and Baretta, J. W.: Link or sink: a modelling interpretation of the open Baltic biogeochemistry, Biogeosciences, 1, 79-100, https://doi.org/10.5194/bg-1-79-2004, 2004.

Vichi, M., Pinardi, N., and Masina, S.: A generalized model of pelagic biogeochemistry for the global ocean ecosystem. Part I: Theory, J. Marine. Syst., 64, 89-109, 2007.

Walls, A. M., Edwards, M. D., Firth, L. B., and Johnson, M. P.: Successional changes of epibiont fouling communities of the cultivated kelp Alaria esculenta: predictability and influences, Aquacult. Env. Interac., 9, 57-71, https://doi.org/10.3354/aei00215, 2017.

West, J., Calumpong, H. P., and Martin, G.: Seaweeds. Chapter 14 in The First Global Integrated Marine Assessment, World Ocean Assessment I, United Nations, available at: www.un.org/ Depts/los/global_reporting/WOA_RegProcess.htm (last access: 19 February 2018), 2016.

White, N. and Marshall, C.: Saccharina latissima. Sugar kelp. Marine Life Information Network: Biology and Sensitivity Key Information Sub-programme, Plymouth: Marine Biological Association of the United Kingdom, available at: www.marlin.ac.uk/ species/detail/1375 (last access: 19 February 2018), 2007.

Wood, D., Capuzzo, E., Kirby, D., Mooney-McAuley, K., and Kerrison, P.: UK macroalgae aquaculture: What are the key environmental and licensing considerations?, Mar. Policy, 83, 29-39, 2017. 